\title{
Alpinites and other Posttornoceratidae (Goniatitida, Famennian)
}

\author{
R. Thomas Becker ${ }^{1}$ \\ With 6 figures, 1 table and 3 plates
}

\begin{abstract}
Summary
The rediscovery of the supposedly lost type allows a revision of Alpinites Bogoslovskiy, 1971, the most advanced genus of the Posttornoceratidae. The type-species, Alp. kayseri Schindewolf, 1923, is so far only known from the Carnic Alps. Alp. schultzei n. sp. from the eastern Anti-Atlas of Morocco is closely related to Alp. kajraktensis n. sp. $(=$ Alp. kayseri in Bogoslovskiy 1971) from Kazakhstan. A second new and more common species of southern Morocco, Alp. zigzag n. sp., is also known from the Holy Cross Mountains (Poland).

The taxonomy and phylogeny of other Posttornoceratidae are discussed. The holotype of Exotornoceras nehdense (Lange, 1929) was recovered and is re-illustrated; it is conspecific with Exot. superstes (Wedekind, 1908). The genus and species is also here first recorded from Morocco. Post. weyeri Korn, 1999 is a subjective synonym of Post. posthumum (Wedekind, 1918) in which strongly biconvex growth lines, as typical for the family, are observed for the first time. Goniatites lenticularis Richter, 1848 is a nomen dubium within Discoclymenia, Clymenia polytrichus in Richter (1848) is a Falcitornoceras. It seems possible to distinguish an extreme thin and trochoid Disco. haueri (Münster, 1840) from the tegoid Disco. cucullata (v. Buch, 1839).

Various taxa are excluded from the Posttornoceratidae. Posttornoceras sapiens Korn, 1999 forms the type-species of Maideroceras n. gen.. Discoclymenia n. sp. of Müller (1956) is assigned to Maid. muelleri $\mathrm{n}$. sp. Disco. cornwallensis is the type-species of Selwoodites n.gen (Sporadoceratidae) which also occurs in the Rhenish Massive.
\end{abstract}

Key words: Ammonoidea, Upper Devonian, taxonomy, phylogeny, Morocco, Carnic Alps, Poland, Germany.

\section{Zusammenfassung}

Durch Auffinden des verschollen geglaubten Typus-Exemplares wird eine Revision der Gattung Alpinites Bogoslovskiy, 1971, der höchst entwickelten Gattung der Posttornoceratidae, möglich. Die Typus-Art, Alp. kayseri Schindewolf, 1923, kommt gesichert bisher nur in den Karnischen Alpen vor. Alp. schultzei n. sp. aus dem östlichen Anti-Atlas (Marokko) ist nah mit Alp. kajraktensis n. sp. aus Kazakhstan (= Alp. kayseri in Bogoslovskiy 1971) verwandt. Eine zweite, aber häufigere neue Art SüdMarokkos, Alp. zigzag n. sp., wird auch im Heiligkreuzgebirge (Polen) nachgewiesen.

Die Taxonomie und Phylogenie anderer Vertreter der Posttornoceratidae werden diskutiert. Der verschollen geglaubte Holotypus von Exotornoceras nehdense (Lange, 1929) wird neu abgebildet und ist conspezifisch mit Exot. superstes (Wedekind, 1908). Die Gattung und Art wird erstmals auch in Marokko nachgewiesen. Post. weyeri Korn, 1999 ist ein subjektives Synonym von Post. posthumum (Wedekind, 1918), bei dem erstmals die Familien-typischen, stark biconvexen Anwachsstreifen beobachtet wurden. Goniatites lenticularis Richter, 1848 ist ein nomen dubium innerhalb von Discoclymenia, Clymenia polytrichus in Richter (1848) ein Falcitornoceras. Es scheint möglich, eine extrem dünne, trochoide Disco. haueri (Münster, 1840) von der tegoiden Disco. cucullata (v. Buch, 1839) zu trennen.

Verschiedene Taxa werden aus den Posttornoceratidae ausgeschlossen. Post. sapiens Korn, 1999 wird als Typus-Art zu Maideroceras n. gen. gestellt. Discoclymenia n. sp. in Müller (1956) wird als Maid. muelleri n. sp. neu beschrieben. Disco. cornwallensis Selwood, 1960 bildet die Typusart von Selwoodites n. gen. (Sporadoceratidae), welches auch im Rheinischen Schiefergebirge vorkommt.

Schlüsselwörter: Ammonoidea, Oberdevon, Taxonomie, Phylogenie, Marokko, Karnische Alpen, Deutschland, Polen.

\section{Introduction}

In his attempt to review the palaeogeography of the European Upper Devonian sea, Schindewolf (1921) mentioned in a faunal list from the Upper Devonian (UD) $\mathrm{V}$ of the Großer Pal (Carnic
Alps, Austrian-Italian border) a new goniatite named as Wedekindoceras kayseri. Both the genus and species were formally described in his later (Schindewolf 1923) monograph on the Famennian ammonoid faunas from the Fichtelgebirge (Bavaria). Wedekindoceras, however, was

\footnotetext{
${ }^{1}$ Museum für Naturkunde, Invalidenstr. 43, D-10115 Berlin/Geologisch-Paläontologisches Institut, Westfälische WilhelmsUniversität Münster, Corrensstr. 24, D-41479 Münster. E-mail: rbecker@uni-muenster.de Received April, accepted July 2002
} 
introduced as an unjustified name replacement (subjective synonym) for Discoclymenia Hyatt whose name seemed inappropiate with respect to its goniatite nature (see discussion in Becker 1995). Knowledge of Disco. kayseri was based on the suture illustration of a single specimen (the holotype) from the Wolayer Thörl (= Valentintörl, not Großer Pal as suggested by the 1921 list) which was deposited at Marburg University. Originally or subsequently no photograph of the holotype has ever been published.

Later, Schindewolf (1944) illustrated the lateral view of a supposed second specimen from Kowala in the Holy Cross Mountains as an example for homoemorphy between Devonian (Discoclymenia) and Carboniferous (Gonioloboceras) ammonoids but no description was provided. Until now, this has remained the only record from Poland. Differences between the figured sutures of both representatives remained unrecognized by Schindewolf and by all later ammonoid workers, including the author. Termier \& Termier (1950) and Petter (1959), for example, added records of Disco. kayseri from North Africa (from near the Oued Rheris, Tafilalt, Morocco, and from Ouarourout in Algeria). In their review of Austrian Palaeozoic ammonoid faunas, Flügel \& Kropfitsch-Flügel (1965) wondered about the whereabouts of the type-specimen and, indeed, it could not be traced at Marburg when the author searched the collection in 1985. Bogoslovskiy (1971) made Disco. kayseri the type of a new genus Alpinites and described 26 specimens from two localities in the Karaganda and Semipalatinsk regions of Kazakhstan. A questionable record of Alpinites sp. from Müssenberg in the Rhenish Slate Mountains (Parawocklumeria paradoxa Zone, UD VI-C) was given in a faunal list in Korn (1981) but remained obscure. Eventually, the author (Becker 1995) described the first Alpinites from the southern Maider of the eastern Anti-Atlas of Morocco and recognized the difference in shell-form between the Maider specimen and the supposedly lost type (both oxyconic) and the Kazakhstan form (rounded venter). Therefore, it was suggested that the latter should be placed in a new species which, however, was not formally named.

The poor knowledge of the Alpinites type and the rarity of the genus prevented further taxonomic progress. The type, however, was recently located in the collection of the Museum für Naturkunde, amongst several specimens borrowed by Schindewolf himself while he was employed in Berlin before the $2^{\text {nd }}$ World War. In addition, sixteen more specimens from the southern Maider became available, by purchase, the authors collecting, or via donations from V. Ebbighausen (Odenthal), J. Bockwinkel (Leverkusen), Z.S. Aboussalam (Berlin) and A. Reisdorf/D. Korn (Tübingen). Alltogether allow a revision of the genus and the separation of various, geographically characteristic species. A number of species of Exotornoceras, Posttornoceras and Discoclymenia are also still insufficiently known and are also revised. In some cases the posttornoceratid affinity previously was still ambiguous, in other cases it will be shown that taxa belong to homoeomorphic sporadoceratid lineages including two new genera. All results will be used for a discussion of the phylogeny of the Posttornoceratidae.

\section{Material, localities and stratigraphy}

\section{Carnic Alps}

As said above, the original label of the holotype of Alp. kayseri (cast MB.C.3440) states that it was found by Emanuel Kayser in UD V (Dasberg-Stufe, Dasbergian) of the Wolayer Thörl (Valentintörl). The Wolayer Lake area does not have good Famennian sections but extremely condensed and fossiliferous cephalopod limestones occur in several small outcrops. Lower Dasbergian (UD V-A) ammonoids are only recorded from a locality near the E. Pichl hut (Gaertner 1931, House \& Price in Schönlaub et al. 1980). The much better and more extensive sections east of the Plöckenpass (e.g. Pramosio area and Großer Pal) have better potential for additional Alpinites specimens. New records were announced by Korn \& House (1997) and by Price \& House (pers. comm.) but are not yet described.

Holy Cross Mts.

The only Polish Alpinites (MB.C.3433), here assigned to Alp zigzag n. sp., was collected by J. Czarnocki in 1935 at Kowala. Nothing is known about the precise stratigraphy of the specimen and the Kowala section with ammonoids ranges from UD IV to VI (Czarnocki 1989).

\section{Southern Maider}

The single specimen (Eb-C1 = holotype of Alp. zigzag n. sp. MB.C.3430) described in Becker (1995) came from Taourart, $11 \mathrm{~km} \mathrm{~S}$ of Fezzou, where beautifully preserved float faunas yielded index forms of UD IV to VI. Six more, partly fragmentary, specimens from Taourart were supplied by V. Ebbighausen (including MB.C.3429) and J. Bockwinkel (including MB.C.3442). Seven further specimens (e.g., MB.C.3428.12, MB.C.3431, MB.C.3432.1, MB.C.3441), including a juvenile (MB.C.3432.2), were purchased locally from Berber people but must have come from the same region around and south of Fezzou. The only biostratigraphically precisely placed specimen is MB.C.3434 (leg. Z.S. Aboussalam) from limestone nodules within Bed $U$ of the Mrakib section which is placed in the regional Gonioclymenia hoevelensis Zone (UD V-B, middle Dasbergian, Becker et al. 2000). A very large-sized second Alpinites from Mrakib (MB.C.3427) was collected by A. Reisdorf and differs from all other Moroccan representatives. It is here assigned to Alp. schultzei $\mathrm{n}$. sp. but its precise stratigraphic age is unclear. A second more incomplete specimen (MB.C.3469) of the same new species was collected by Z.S. Aboussalam in the orbiculare marker bed at Mrakib (see section log in Becker et al. 2000) and falls in the upper orbiculare Zone (UD IV-C). 
Abbreviations: Gon, $=$ Goniatites, Alp. $=$ Alpinites, Post . $=$ Posttornoceras, Exot.$=$ Exotornoceras, Sporad.$=$ Sporadoceras, Disco. $=$ Discoclymenia, Maid. $=$ Maideroceras n. gen. $\mathrm{Dm}=$ diameter, $w h=$ whorl height, ah $=$ apertural height, $w w=$ whorl width, $\mathrm{WER}=$ whorl expansion rate $=$ $(\mathrm{dm} / \mathrm{dm}-\mathrm{ah})^{2}, \mathrm{E}=$ ventral lobe, $\mathrm{A}=$ adventitious lobes, $\mathrm{L}=$ lateral lobes, $\mathrm{L}_{1 \mathrm{v} / 1 \mathrm{i}}=$ outer/inner first lateral lobe, $\mathrm{I}=$ dorsal lobe. Specimens with MB.C. numbers are housed in the Museum für Naturkunde, specimens with $X$ numbers are deposited in the collection of the Bundesanstalt für Geowissenschaften und Rohstoffe (BGR) in Berlin-Spandau.

\section{Systematic Palaeontology}

\section{Posttornoceratidae Bogoslovsky, 1962 emend.}

Included genera: Exotornoceras s.str. (superstes Group), Posttornoceras, Discoclymenia, Alpinites.

Discussion: The author has reviewed the family and summarized its main apomorphies (Becker 1995). An unsolved question is the relationship between early (UD II: Exot. superstes) and late (UD V/VI: Exot. fezzouense, ?Exot. syl- viae) members of the ancestral genus Exotornoceras. It is strange that the oldest species is morphologically more advanced ( $A_{1}$ angular) than the younger ones $\left(A_{1}\right.$ well rounded). In the meantime (e.g., Becker et al. 2000) many more Famennian tornoceratids have been collected without evidence for any Exotornoceras in UD III/IV. This raises the suspicion, supported by morphological similarities, that the Exot. fezzouense Group was independently derived in the earliest Dasbergian from Gundolficeras with rounded $\mathrm{A}_{1}$ whilst Exotornoceras s.str., the ancestor of all other Posttornoceratidae, does not range above the Nehdenian (UD II). As a consequence, the fezzouense Group may have to be placed in a new genus of the Falcitornoceratini. The Posttornoceratidae need to be redefined to include only taxa with three lateral lobes and angular (at maturity) adventitious and $\mathrm{L}_{1}$-lobes. The adult WER ranges from 2.4 to 2.85 .
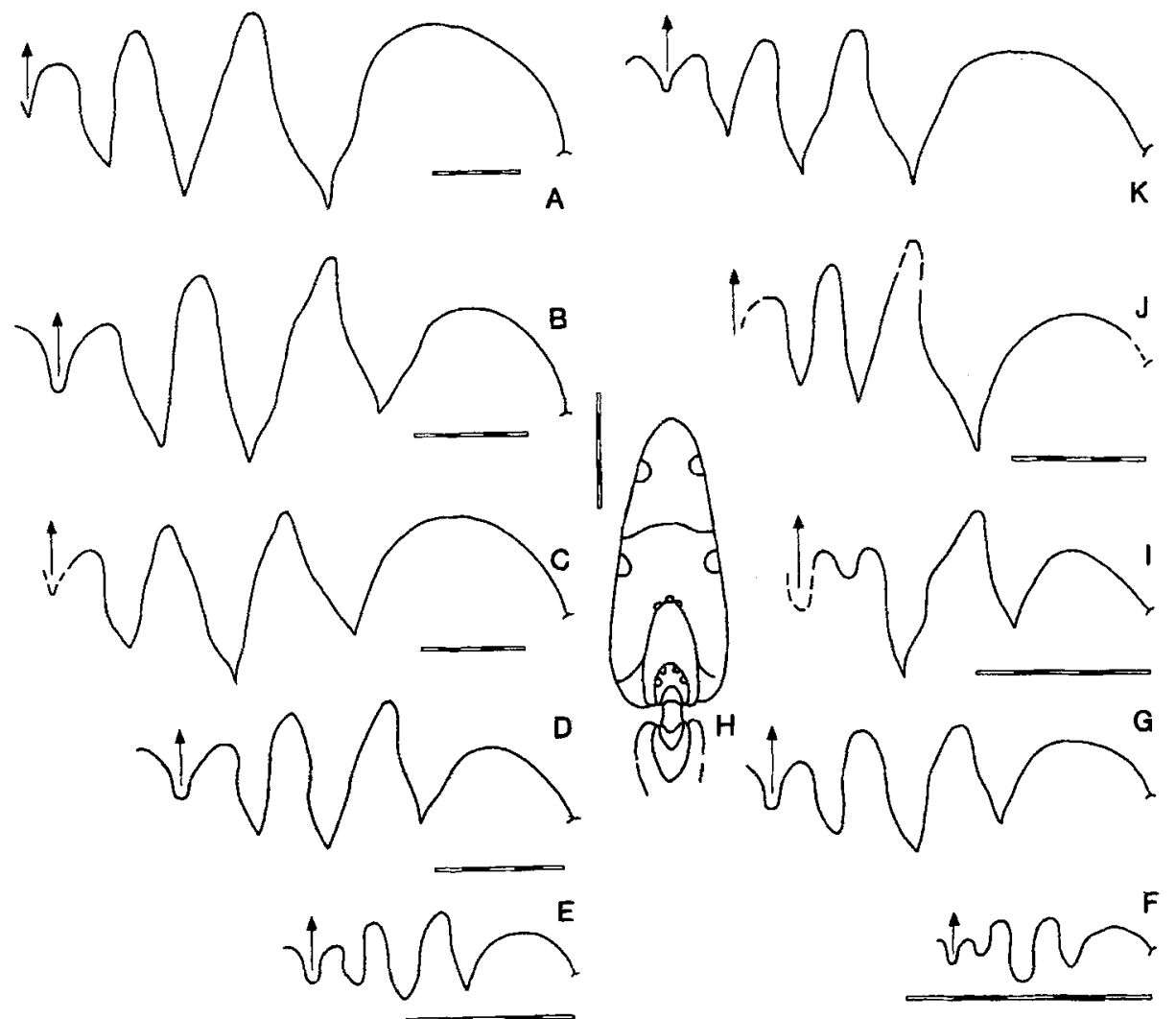

Fig. 1. Sutures and cross-section of Alpinites. Scale bar $=5 \mathrm{~mm}$. A. Alp. schultzei $\mathrm{n}$. sp., MB.C.3427, holotype from Mrakib, leg. A. Reisdorf, suture (reversed) at $29.6 \mathrm{~mm}$ wh, B. Alp. zigzag n. sp., MB.C.3428.1, paratype, loose from the Fezzou area, purchased by the author, suture (reversed) at $24.2 \mathrm{~mm}$ wh, C. Alp. zigzag n. sp., MB.C.3433, original of Schindewolf (1944, 1950) from Kowala, suture (reversed) at $24.7 \mathrm{~mm}$ wh, D. Alp. zigzag n. sp., MB.C.3431, paratype from the Fezzou area, ded. J. Bockwinkel, suture at $15.4 \mathrm{~mm}$ wh, E. Alp. zigzag n. sp., MB.C.3432.1, paratype, loose from the Fezzou area, ded. V. Ebbighausen, suture (reversed) at $7.5 \mathrm{~mm}$ wh, F. Alp. zigzag n. sp., MB.C.3432.2, paratype, loose from the Erfoud area, purchased by V. Ebbighausen, suture (reversed) at $3.5 \mathrm{~mm}$ wh, G. Alp. zigzag n. sp., MB.C.3441, paratype, loose from the Fezzou area, ded. V. Ebbighausen, suture (reversed) at $10.6 \mathrm{~mm}$ wh, H. Alp. zigzag n. sp., MB.C.3442, paratype from Taourart, leg. J. Bockwinkel, incomplete cross-section at 14.8 max. wh, I. Disco. haueri, MB.C.3439, Malpasso, Bed 7c, leg. by the author in 2001, suture (reversed) at $9.7 \mathrm{~mm}$ wh, J. Alp. kayseri, MB.C. 3440, holotype and original of Schindewolf (1923) from the Wolayer Thörl, suture at $15.6 \mathrm{~mm}$ wh, K. Alp. kajraktensis n. sp., Palaeontological Museum, Moscow, 1683/901, holotype and original of Bogoslovskiy (1971) from the Karaganda area of Kazakhstan, suture at $31.6 \mathrm{~mm}$ wh. 


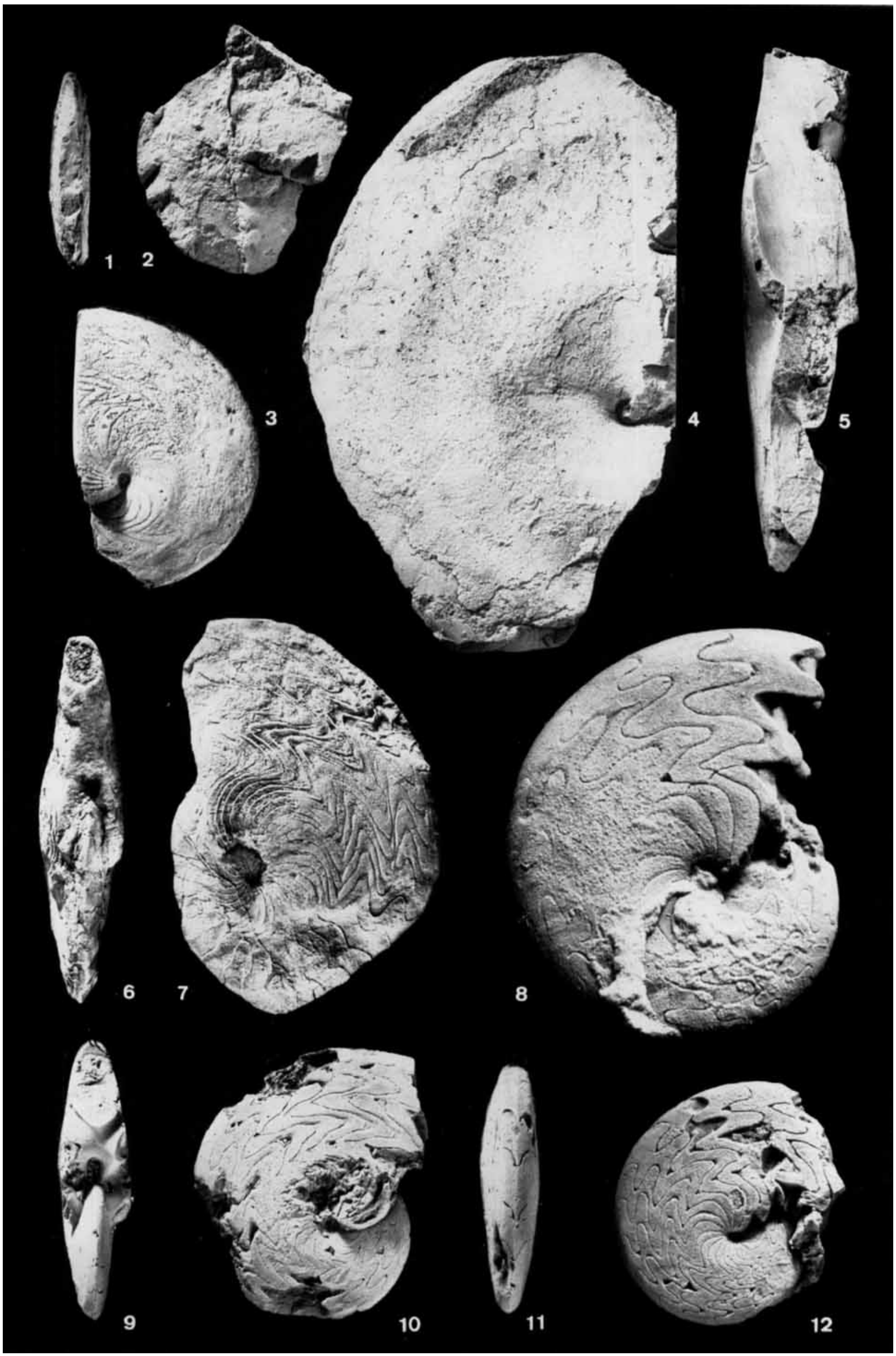




\section{Alpinites Bogoslovsky, 1971}

Type-species: Wedekindoceras kayseri Schindewolf, 1923.

Diagnoses: Venter narrowly rounded to oxyconic, strongly compressed, umbilicus closed, wh fast expanding (adult WER ca. 2.4-2.65); growth lines strongly biconvex with short dorsolateral salient, deep flank sinus and high, broad ventrolateral salient; with three pointed lobes on the flanks and with narrow, subangular mid-flank saddles. Sutural formula: $\mathrm{EA}_{2} \mathrm{~A}_{1} \mathrm{~L}_{1 \mathrm{v}} \mathrm{L}_{2}: \mathrm{L}_{1 \mathrm{i}} \mathrm{I}$.

Discussion: Discoclymenia has a much smaller and rounded $\mathrm{A}_{2}$ and possesses ventrolateral furrows lying in a narrow apertural projection at young stages. Posttornoceras and Exotornoceras lack an $\mathrm{A}_{2}$. The sutural ontogeny of the Posttornoceratidae was shown for Exotornoceras and Discoclymenia by Becker (1995) but earliest sutural stages of Alpinites are not yet known.

Distribution: Carnic Alps, Poland, Morocco, Algeria, Kazakhstan.

Stratigraphical range: As far as known, uppermost Hembergian (UD IV-C) to middle Dasbergian (UD V-B).

\section{Alpinites kayseri (Schindewolf, 1923)}

Figs 1J, 2B, Pl. 1: 1-2

v 1921 Wedekindoceras kayseri - Schindewolf: 185 [nomen nudum]

* ${ }_{\mathrm{v}} 1923$ Wedekindoceras kayseri n. sp. - Schindewolf: 354, fig. $9 b$

v non 1944 Discoclymenia kayseri - Schindewolf: fig. 20 $[=$ Alp. zigzag n. sp. $]$

non 1950 Discoclymenia kayseri - Termier \& Termier: 60, pl. CXLVI, figs 23-25 [= Alp. aff. schultzei n. sp.]

non 1959 Discoclymenia kayseri - Petter: 212, pl. XV, figs 17-18 [= Alp. sp.]

v non 1971 Alpinites kayseri -- Bogoslovsky: 32-34, 92-94, figs $26 \mathrm{~b}, 27$, pl. IV, figs $11-12$, Pl. V, fig. 1 [=Alp. kajraktensis n. sp.]

v 1980 Alpinites kayseri - House \& Price in Schönlaub et al.: 15

v non 1995 Alpinites kayseri - Becker: 624-625, fig. 8a, pl. 3, figs 8-11 [= Aip. zigzag n. sp.]

Type: Holotype MB.C.3430 (cast, leg. E. Kayser, originally from the collection of the Phillips University Marburg).
Material: Only the holotype.

Diagnosis: Extremely thinly discoidal, flanks flattened, strongly converging to a (?sub)oxyconic venter; with decreasing depths of lobes from the inner flank to the venter, $L_{1 v}$ much deeper than $A_{1}$; inner $L_{2}-L_{1 v}$ saddle much lower than the mid-flank subangular $\mathrm{L}_{1 \mathrm{v}}-\mathrm{A}_{1}$ saddle and also lower than the outer flank $\mathrm{A}_{1}-\mathrm{A}_{2}$ saddle, the saddle height decreases from the middle of the whorl outwards.

Description: The holotype is rather poorly preserved and incomplete but shows well the distinctive outer suture (Fig. 1J). Precise measurements of shell parameters are hard to give. At ca. $14.5 \mathrm{wh}$, ww is close to $6 \mathrm{~mm}$. Corrosion of the venter by pressure solution prevents a clear diagnosis of the whorl profile. Schindewolf thought that the species is sphenoidic but the venter just as well may have been only suboxyconic. Schindewolfs (1923) sutural drawing is rather accurate but the first external L-lobe has a narrower pointed base and $A_{2}$ is somewhat deeper than originally shown. Also, the midflank saddles are not quite as angular and triangular but have a very narrow rounded top at ca. $14 \mathrm{~mm}$ wh. The (outer) ventral saddle is lower than the mid-flank saddles but still higher than the inner flank saddle.

Discussion: It is unfortunate that the species was based on such a poor specimen (see Pl. 1: $1-2)$. Forms with similarly deep $L_{1 v}$ lobe from North Africa and Kazakhstan, here assigned to new species, have higher inner flank saddles, a rounded venter and obviously less converging flanks. Currently the species is restricted to the Carnic Alps.

Stratigraphical range: Not precisely known, most likely Dasbergian (UD V).

\section{Alpinites schultzei n. sp.}

Figs 1A, 2A, 2B, Pl. 1: 3-5

aff. 1950 Discoclymenia kayseri - Termier \& Termier: 60, pl. CXLVI, figs $23-25$

Plate 1. 1-2. Alpinites kayseri (Schindewolf), MB.C.3440, Wolayer Thörl, UD V, original of Schindewolf (1923: fig. 9b), ventral and lateral views, showing strong shell compression and poor preservation, $\times 1$. 3-5. Alpinites schultzei n. sp., MB.C.3427, holotype, Mrakib, UD IV-A/V-A, leg. A. Reisdorf, lateral view of phragmocone showing sutures, lateral view of body chamber, showing the spiral flank depressions and growth lines, slightly oblique ventral view, $\times 1.6-7$. Alpinites zigzag $\mathrm{n}$. sp., MB.C.3433, Kowala, ?UD V, original of Schindewolf $(1944,1950)$, adoral and lateral views, $\times 1.5$. 8. Alpinites zigzag n. sp., MB.C.3432.2, juvenile paratype, southern Maider, UD V, ded. V. Ebbighausen, lateral view, showing early ontogenetic rounded flank lobes, with a dominant $\mathrm{A}_{1}, \times 6,9$-10. Alpinites zigzag n. sp., MB.C.3429, paratype, Taourart, UD V, leg. V. Ebbighausen, adoral and lateral views, $\times$ 1.5. 11-12. Alpinites zigzag n. sp., MB.C.3432.1, paratype, southern Maider, UD V, ded. V. Ebbighausen, ventral and lateral views, $\times 2$. 
? non 1959 Discoclymenia kayseri - Petter: 212, Pl. XV, figs $17-18$

Material: Holotype MB.C.3427 (leg. A. Reisdorf, Pl. 1: 3-5), paratype MB.C.3469 (leg. Z.S. Aboussalam).

Derivation of name: On the occasion of his $65^{\text {th }}$ birthday in honour of Prof. H.-P. Schultze, director of the Museum für Naturkunde, Berlin.

Type locality and level: Mrakib, southern Maider, UD IV-C N-A.

Diagnosis: Extremely compressed, with flattened, only slightly converging flanks, venter narrowly rounded, whorls fast expanding (adult
WER decreasing from 2.6 to 2.4 ), with two characteristic mid- and outer flank spiral depressions from at least $20 \mathrm{~mm}$ wh on; $\mathrm{L}_{1 \mathrm{v}}$ only slightly deeper than $A_{1}$ which is deeper than the asymmetric $A_{2} ; L_{2}-L_{1 v}$ saddle almost as high as the subangular mid-flank saddle and higher than the outer ventral saddle.

Description: The species reached more than $120 \mathrm{~mm}$ diameter which makes it the largest known member of the genus and family. The double depressions separated by a narrow, shallow and rounded ridge give it a very characteris-

Table 1

Shell parameters (in $\mathrm{mm}$ ) of various Posttomoceratidae and of some Sporadoceratidae.

\begin{tabular}{|c|c|c|c|c|c|c|c|c|c|}
\hline & $\mathrm{dm}$ & Wh & ah & ww & $\mathrm{wh} / \mathrm{dm}$ & $\mathrm{ah} / \mathrm{dm}$ & $\mathrm{ww} / \mathrm{dm}$ & ww/wh & WER \\
\hline \multicolumn{10}{|l|}{ Exot. "nehdense" } \\
\hline MB.C.3435 & 17.2 & 10.6 & 7.0 & 8.55 & 0.62 & 0.41 & 0.5 & 0.81 & 2.84 \\
\hline \multicolumn{10}{|l|}{ Post. contiguum } \\
\hline $\begin{array}{l}\text { MB.C. } 3462 \\
\text { MB.C.3454 } \\
\text { MB.C.3455 }\end{array}$ & $\begin{array}{l}21.5 \\
23.1 \\
25.3\end{array}$ & $\begin{array}{l}13.6 \\
16.4 \\
16.2\end{array}$ & $\begin{array}{c}8.2 \\
9.4 \\
--\end{array}$ & $\begin{array}{l}12.5 \\
12.5 \\
13.2\end{array}$ & $\begin{array}{l}0.63 \\
0.71 \\
0.64\end{array}$ & $\begin{array}{l}0.38 \\
0.41 \\
-\end{array}$ & $\begin{array}{l}0.58 \\
0.54 \\
0.52\end{array}$ & $\begin{array}{l}0.92 \\
0.76 \\
0.82\end{array}$ & $\begin{array}{l}2.61 \\
2.84 \\
-\end{array}$ \\
\hline \multicolumn{10}{|l|}{ Post. aff. contiguum } \\
\hline $\begin{array}{l}\text { MB.C. } 3457 \\
\text { MB.C. } 3458\end{array}$ & $\begin{array}{r}6.8 \\
12.7\end{array}$ & $\begin{array}{l}4.6 \\
8.7\end{array}$ & - & $\begin{array}{l}4.5 \\
7.2\end{array}$ & $\begin{array}{l}0.68 \\
0.66\end{array}$ & $\overline{0.41}$ & $\begin{array}{l}0.66 \\
0.57\end{array}$ & $\begin{array}{l}0.98 \\
0.83\end{array}$ & $\overline{2.87}$ \\
\hline \multicolumn{10}{|l|}{ Post. posthumum } \\
\hline $\begin{array}{l}\text { MB.C. } 3453.4 \\
\text { MB.C. } 2176 \text { (neotype) } \\
\text { MB.C.3451 } \\
\text { MB.C.3465.1 } \\
\text { MB.C.1697 (Schüb.) } \\
\text { MB.C.3446 } \\
\text { Gött. } 389-59 \text { (lectotype) } \\
\text { MB.C.3465.1 }\end{array}$ & $\begin{array}{l}14.8 \\
24.0 \\
30.8 \\
34.0 \\
50.0 \\
50.0 \\
51.0 \\
58.7\end{array}$ & $\begin{array}{r}8.7 \\
15.8 \\
19.8 \\
21.0 \\
34.0 \\
34.5 \\
32.0 \\
35.4\end{array}$ & $\begin{array}{l}5.9 \\
- \\
11.5 \\
12.5 \\
18.8 \\
19 \\
\text { ca. } 19 \\
21.3\end{array}$ & $\begin{array}{l}\quad 9.4 \\
\text { ca. } 14.8 \\
17.8 \\
23.5 \\
25.0 \\
27.6 \\
26 \\
35.1\end{array}$ & $\begin{array}{l}0.59 \\
0.66 \\
0.64 \\
0.62 \\
0.68 \\
0.69 \\
0.63 \\
0.60\end{array}$ & $\begin{array}{l}0.40 \\
- \\
0.37 \\
0.37 \\
0.38 \\
0.38 \\
0.37 \\
0.36\end{array}$ & $\begin{array}{l}0.64 \\
\text { ca. } 0.62 \\
0.58 \\
0.69 \\
0.50 \\
0.55 \\
0.51 \\
0.60\end{array}$ & $\begin{array}{l}1.08 \\
\text { ca. } 0.94 \\
0.90 \\
1.12 \\
0.74 \\
0.80 \\
0.84 \\
0.99\end{array}$ & $\begin{array}{l}2.77 \\
- \\
2.55 \\
2.50 \\
2.57 \\
2.60 \\
2.54 \\
2.46\end{array}$ \\
\hline \multicolumn{10}{|l|}{ Disco. haueri } \\
\hline $\begin{array}{l}\text { MB.C.3439 } \\
\text { MB.C.3443 }\end{array}$ & $\begin{array}{l}17.5 \\
40.0\end{array}$ & $\begin{array}{l}10.8 \\
26.3\end{array}$ & $\begin{array}{l}- \\
-\end{array}$ & $\begin{array}{l}5.2 \\
\text { ca. } 10\end{array}$ & $\begin{array}{l}0.62 \\
0.66\end{array}$ & $\begin{array}{l}- \\
-\end{array}$ & $\begin{array}{l}0.30 \\
0.25\end{array}$ & $\begin{array}{l}0.48 \\
0.38\end{array}$ & - \\
\hline \multicolumn{10}{|l|}{ Alp. schultzei n. sp. } \\
\hline $\begin{array}{l}\text { MB.C.3427 } \\
\text { MB.C.3469 }\end{array}$ & $\begin{array}{l}52.7 \\
99.0\end{array}$ & $\begin{array}{l}31.5 \\
59.0\end{array}$ & $\begin{array}{l}20.1 \\
\text { ca. } 35\end{array}$ & $\begin{array}{l}13.5 \\
16.0\end{array}$ & $\begin{array}{l}0.60 \\
0.60\end{array}$ & $\begin{array}{l}0.38 \\
\text { ca. } 0.35\end{array}$ & $\begin{array}{l}0.26 \\
0.16\end{array}$ & $\begin{array}{l}0.43 \\
0.27\end{array}$ & $\begin{array}{l}2.61 \\
\text { ca. } 2.4\end{array}$ \\
\hline \multicolumn{10}{|l|}{ Alp. zigzag n. sp. } \\
\hline $\begin{array}{l}\text { MB.C. } 3442 \\
\text { MB.C. } 3442 \\
\text { MB.C. } 3432.2 \\
\text { MB.C. } 3432.1 \\
\text { MB.C. } 3431 \\
\text { MB.C. } 3430 \\
\text { MB.C. } 3433 \text { (Kowala) }\end{array}$ & $\begin{array}{l}4.3 \\
9.0 \\
12.6 \\
23.0 \\
29.4 \\
34.0 \\
\text { ca. } 48\end{array}$ & $\begin{array}{l}2.55 \\
5.5 \\
7.8 \\
13.9 \\
18.4 \\
20.4 \\
\text { ca. } 29.5\end{array}$ & $\begin{array}{l}1.3 \\
3.6 \\
5.0 \\
- \\
\text { ca. } 11 \\
12.4 \\
\text { ca. } 17\end{array}$ & $\begin{array}{c}1.6 \\
2.8 \\
3.3 \\
5.8 \\
8 \\
8.7 \\
10.4\end{array}$ & $\begin{array}{l}0.61 \\
0.61 \\
0.62 \\
0.60 \\
0.63 \\
0.60 \\
\text { ca. } 0.62\end{array}$ & $\begin{array}{l}0.30 \\
0.40 \\
0.40 \\
- \\
\text { ca. } 0.38 \\
0.37 \\
\text { ca. } 0.36\end{array}$ & $\begin{array}{l}0.37 \\
0.31 \\
0.26 \\
0.25 \\
0.27 \\
0.26 \\
\text { ca. } 0.22\end{array}$ & $\begin{array}{l}0.62 \\
0.51 \\
0.42 \\
0.42 \\
0.44 \\
0.43 \\
\text { ca. } 0.35\end{array}$ & $\begin{array}{l}2.05 \\
2.78 \\
2.75 \\
- \\
\text { ca. } 2.55 \\
2.48 \\
\text { ca. } 2.4\end{array}$ \\
\hline \multicolumn{10}{|l|}{ Maid. sapiens } \\
\hline $\begin{array}{l}\text { MB.C. } 3447.1 \\
\text { MB.C. } 3476.1 \\
\text { MB.C. } 3471 \\
\text { MB.C. } 3477\end{array}$ & $\begin{array}{r}8.9 \\
10.5 \\
13.7 \\
16.8\end{array}$ & $\begin{array}{r}5.3 \\
6.7 \\
8.7 \\
10.0\end{array}$ & $\begin{array}{l}3.2 \\
3.9 \\
4.8 \\
5.9\end{array}$ & $\begin{array}{c}\text { ca. } 4.3 \\
5.2 \\
4.9 \\
7.4\end{array}$ & $\begin{array}{l}0.60 \\
0.64 \\
0.64 \\
0.60\end{array}$ & $\begin{array}{l}0.36 \\
0.37 \\
0.35 \\
0.35\end{array}$ & $\begin{array}{l}\text { ca. } 0.48 \\
0.50 \\
0.36 \\
0.44\end{array}$ & $\begin{array}{l}\text { ca. } 0.81 \\
0.78 \\
0.56 \\
0.74\end{array}$ & $\begin{array}{l}2.44 \\
2.53 \\
2.37 \\
2.38\end{array}$ \\
\hline \multicolumn{10}{|l|}{ Maid. muelleri n. sp. } \\
\hline
\end{tabular}


tic shell form. The inner spiral depression is more marked (Pl. 1: 4). It is unclear at which stage these furrows appear but despite grinding during suture preparation they can be weakly recognized on the phragmocone of the holotype. The body chamber of the latter includes an embedded Phacops granulatus (MB.T.4580) and displays the biconvex growth lines (Pl. 1: 4) with a relative broad ventrolateral salient and a wider but less prominent inner flank salient. The lateral sinus occupies the are of the main mid-flank depression. The paratype broke at the last septum, suggesting a body chamber angle of $200-210^{\circ}$. For measurements see Table 1 . WER seems to decrease at late maturity.

Discussion: At $50 \mathrm{~mm}$ dm sutures (Fig. 1A) have a deep $\mathrm{L}_{1 \mathrm{v}}$ as in Alp. kayseri but the venter is narrowly rounded and the flanks converge only slightly. The new species differs also in the much higher inner flank saddle at comparable size (at least from ca. $15 \mathrm{~mm}$ wh on) and much deeper $A_{1}$ in relation to the $L_{1 v}$. The Algerian kayseri specimen figured by Petter (1959: pl. XV, fig. 18) also is not oxyconic and displays $L_{1 v}$ lobes which are deeper than the $A_{1}$ lobes, which again are deeper than the small pointed $A_{2}$. But the $A_{1}-A_{2}$ saddle is unusual low, as in Discoclymenia, and Petters form cannot be assigned to any of the species described here. Termier \& Termier (1950) figured an Alpinites with tegoid, rounded cross-section from the Tafilalt which also has two rather low ventral saddles, with the outer one beeing even higher than the inner. Without re-exanimation the drawings are difficult to interprete; therefore, this specimen is preliminarily identified as Alp. aff. schultzei.

Stratigraphical range: The precise level of the holotype is unknown. The paratype comes from the uppermost Hembergian orbiculare Bed (upper UD IV-C).

\section{Alpinites kajraktensis n. sp.}

Figs 1K, 2A, 2B

v 1971 Alpinites kayseri - Bogoslovsky: 32-34, 92-94, figs 26b, 27, pl. IV, figs $11-12$, Pl. V, fig. 1

v 1995 Alpinites n. sp. - Becker: 625

Type: Palaeontological Museum of the Academy of Sciences, Moscow, holotype no. 1683-901, figured by Bogoslovskiy (1971: fig. 27b, pl. IV, fig. 12). The Moscow originals have been examined in 1998. The designated type shows best the sutures and whorl form. Two other apparently more complete specimens figured on pls IV (1683-900) and V (1683-664) are in fact mostly restored and less suitable.

Derivation of name: After the type locality.
Type locality and level: Kajrakty River, Karaganda Basin, Kazakhstan, topmost Hembergian (UD IV-C) or basal Dasbergian (UD V-A1).

Diagnosis: Medium-sized, flanks flattened, gently converging to a narrowly rounded venter, whorls fast expanding (adult WER 2.5 to 2.6), without spiral furrows; $L_{1 v}$ only slightly deeper than the asymmetric $A_{1}$ which, again, is deeper than $A_{2} ; L_{2}-L_{1 v}$ saddle almost as high as the narrow and adult subangular $\mathrm{L}_{1 \mathrm{v}}-\mathrm{A}_{1}$ and $\mathrm{A}_{1}-\mathrm{A}_{2}$ saddles.

Discussion: The new species differs from Alp. kayseri in cross-section and suture outline (Fig. $1 \mathrm{~K}$ ), especially in the higher inner flank saddle and deeper $\mathrm{A}_{1}$ lobes at comparable size. It lacks the lateral depressions of the larger Alp. schultzei $\mathrm{n}$. sp. with has similar sutures and shell compression (Figs 2A, 2B). There is no evidence for incipient $\mathrm{A}_{3}$ lobes as indicated in Bogoslovskiy's suture drawings.

Stratigraphical range: Bogoslovskiy (1971: faunas 18 and 19a) placed his Kazakhstan specimens in UD IV since the index genera Prionoceras and Platyclymenia were found in the same faunas. However he also mentions Costaclymenia (now placed in synonymy with Endosiphonites) which enters in Morocco and Germany (Becker et al. 2000, Korn et al. 2000) at the very base of UD V. Therefore, a basalmost Dasbergian age (UD V-A1) is also possible for (some) central Asian Alpinites.

\section{Alpinites zigzag n. sp.}

Figs 1B-H, 2A, 2B, Pl. 1: 6-13

v 1944 Discoclymenia kayseri - Schindewolf: fig. 20

v 1950 Discoclymenia kayseri - Schindewolf: pl. XXXII, fig. 330

v 1995 Alpinites kayseri - Becker: 624-625, fig. 8a, pl. 3, figs $1-2$

v 2000 Discoclymenia sp. - Keupp: unnumbered upper left figure on p. 60

Type: Holotype MB.C.3430 (= Eb-C1), previously illustrated by Becker (1995: pl. 3, figs 1-2).

Derivation of name: After the zigzag-pattern of its sutures.

Type locality and horizon: Taourart S of Fezzou, Maider, southern Morocco (see map in Becker, 1995); Fezzou Shales, Clymenia Stufe (UD V).

Material: The holotype, paratype MB.C.3434 from Mrakib/ Bed U, purchased paratypes MB.C.3428.1-2 and MB.C.3431 (presented by J. Bockwinkel), paratypes MB.C.3432.1-2 (PI. 1: 8-9, 12-13) and MB.C.3441 (presented by V. Ebbighausen), paratypes MB.C.3429 (leg. V. Ebbighausen, Pl. 1: 10-11) and MB.C.3442 (leg. J. Bockwinkel) from Taourart, five additional Maider specimens, MB.C.3433 from Kowala (original of Schindewolf 1944, 1950; see Pl. 1: 6-7). 

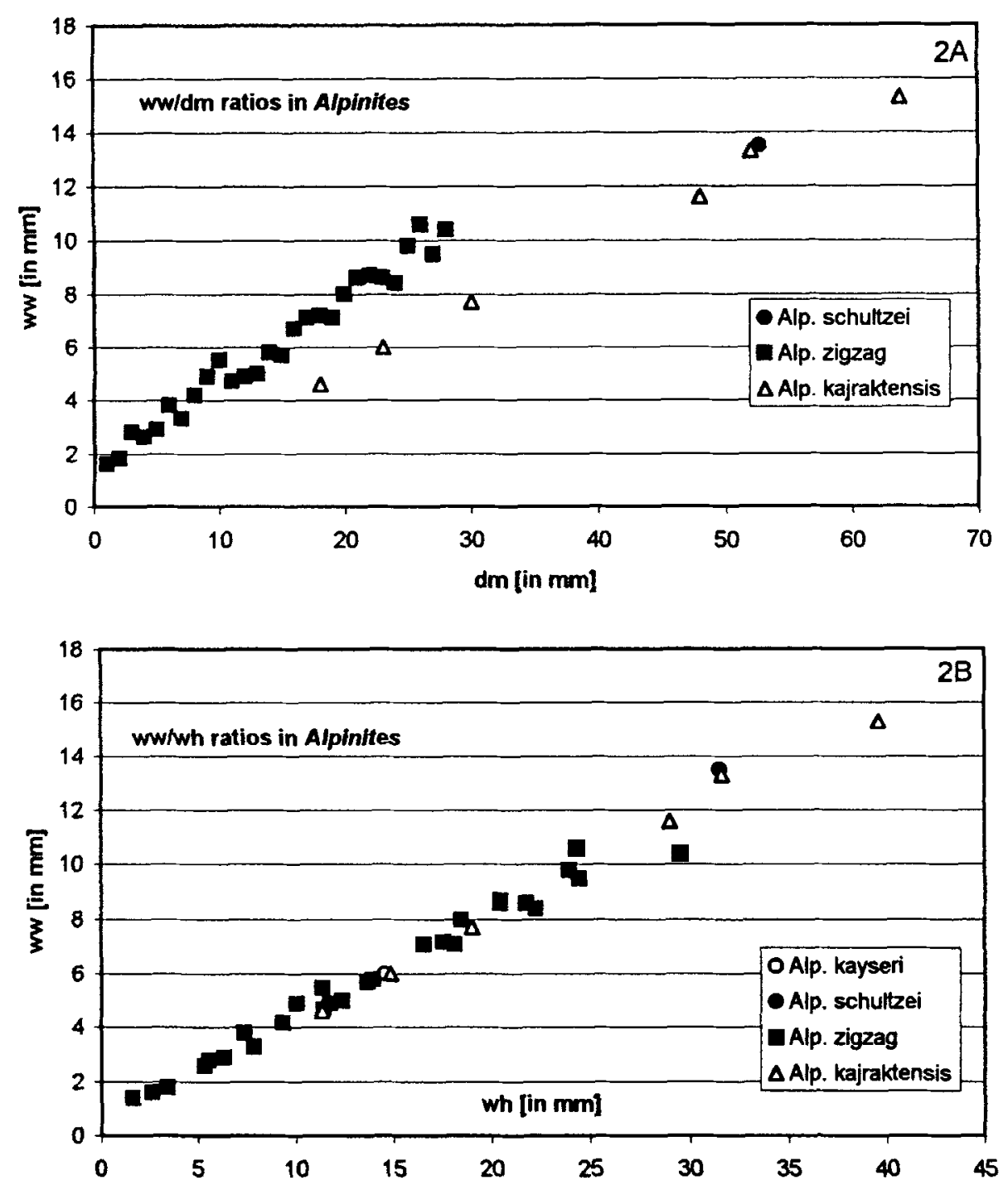

Fig. 2. Ww/dm (A) and ww/wh plots for Alp. kayseri, Alp. schultzei n. sp., Alp. kajraktensis n. sp. (based on measurements of Bogoslovskiy 1971), and Alp. zigzag $\mathrm{n}$. sp. The latter species is somewhat thicker than the others (A) but all have nearly identical ww/wh ratios.
Diagnoses: Extremely thin and discoidal throughout ontogeny, venter oxyconic but with rounded shoulders from very early stages (ca. $5 \mathrm{~mm}$ diameter) on. Following an initial rise, WER decreases from almost 2.8 (at ca. $9 \mathrm{~mm}$ $\mathrm{dm})$ to ca. 2.5-2.6. at maturity; adult sutures with much deeper $A_{1}$ than $L_{1 v}$; the outer flank $A_{2}$ becomes as deep or deeper than $L_{1 v}$ at maturity; from the mid-flank $L_{1 v}-A_{1}$ saddle on, the height of saddles declines towards the venter, the ventral $\left(A_{2}-E\right)$ saddle beeing rather broad and asymmetric; $\mathrm{E}$ is funnel-shaped.

Description: Early stages are visible in some broken haematitic moulds (e.g., MB.C.3442, Fig. $1 \mathrm{H})$. The smallest complete individual (MB.3432.2, Pl. 1: 12-13) has a diameter of $12.5 \mathrm{~mm}$. Some shell parameters are given in Table 1 (see also Fig. 2). Already at $3 \mathrm{~mm}$ diameter conches are strongly compressed and the venter

Plate 2. 1-2. Posttornoceras posthumum (Wedekind), MB.C.3451, southern Maider, probably UD V, lateral and adoral views, $\times$ 1.6. 3-4. Exotornoceras superstes (Wedekind), MB.C.3435, holotype of Manticoceras nehdense Lange (1929), Nehden, probably UD II-D, lateral and adoral views, $\times$ 3. 5-6. Posttornoceras aff. contiguum (Münster) juv., MB.C.3457, Mrakib, Bed $\mathrm{J}_{1}$, UD III-C1, lateral and ventral views, showing marked marginal furrows, $\times 4.1$. 7-8. Posttornoceras aff. contiguum (Münster) juv., MB.C.3458, Mrakib, Bed $\mathrm{H}_{2}$, UD III-C1, lateral view, $\times 3$, ventral view, showing marginal furrows, $\times 4$. 9-10. Posttornceras posthumum (Wedekind), MB.C.3446, southern Maider, probably UD V, lateral and ventral views, $\times 1$. 11-12. Posttornoceras posthumum (Wedekind), MB.C.2176, neotype of Becker (1997: fig. 1b), Hövel, UD V, lateral and ventral views, showing the typical inflated whorl profile, $\times 1.5$. 13-14. Posttornoceras contiguum (Münster), MB.C.3454, Enkeberg, level unknown, leg. L. v. Buch, originally identified as Gon. bilanceolatus, lateral and adoral views, $\times 2$. 15-16. Posttornoceras contiguum (Münster), MB.C.3455, Enkeberg, Bed 18, upper Nehdenian, leg. W. Paeckelmann, originally identified as Sporad. cf. contiguum, lateral and ventral views, $\times 2$. 

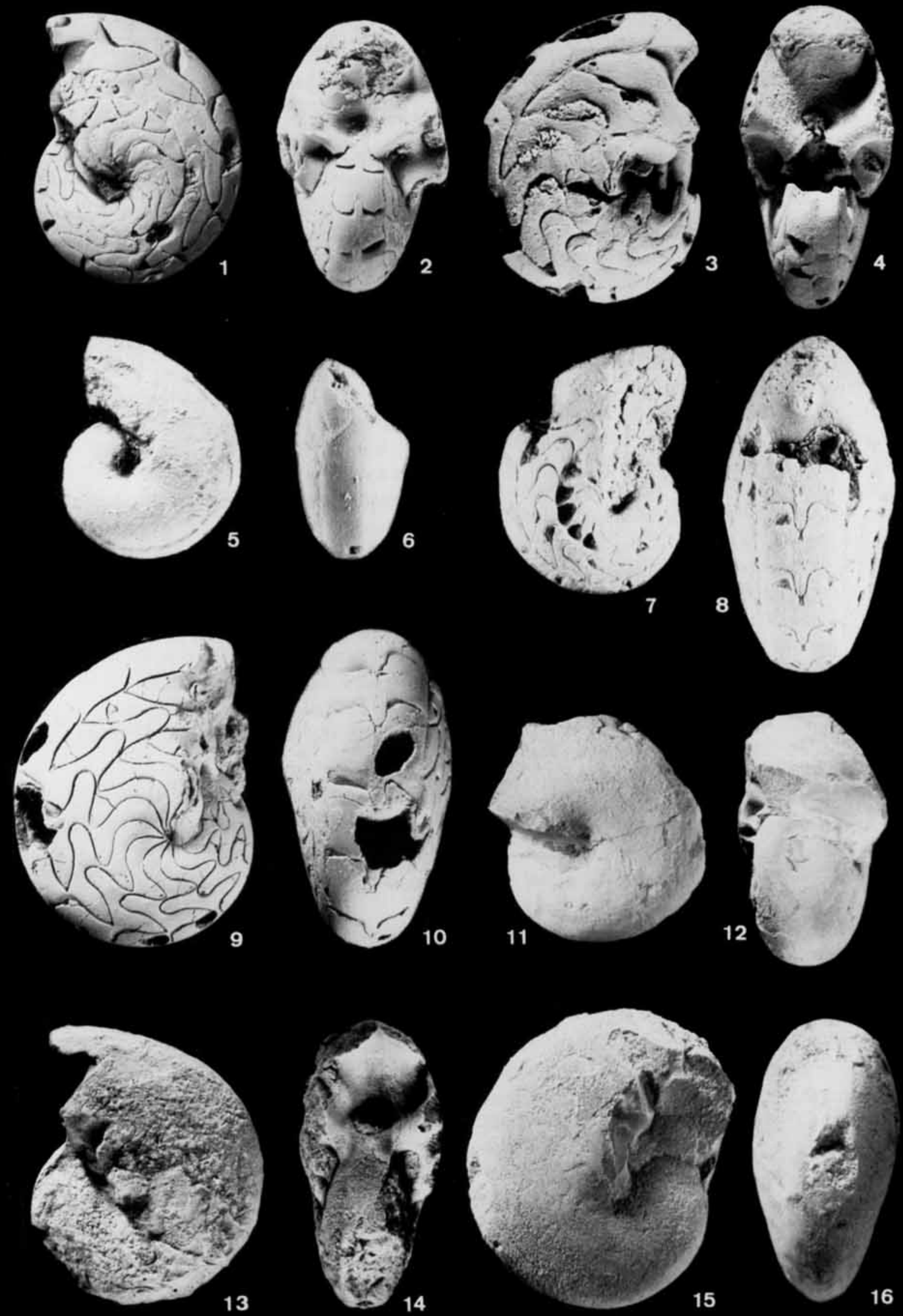
starts to sharpen around $5 \mathrm{~mm} \mathrm{dm}$. The flanks are generally flatly rounded and converge to round ventral shoulders which border a sharp mid-ventral edge. Worn specimens may not show the fully oxyconic whorl type. The whorl expansion rate lies around 2.0 in early stages, rises almost to 2.8 at $9 \mathrm{~mm} \mathrm{dm}$ and gradually decreases to ca. 2.6 in the holotype (at $34 \mathrm{~mm} \mathrm{dm}$ ) and in MB.C.2429 (at $35 \mathrm{~mm} \mathrm{dm}$ ). Larger specimens such as MB.C.3433 may have even lower WER (ca. 2.4), suggesting a similar trend as in Alp. schultzei $\mathrm{n}$. sp.

Most specimens show only weak imprints of undulose growth ornament which suggest a relative broad, but very high, prorsiradiate ventrolateral salient occupying the flanks from the position of the $A_{1}$ lobe on outwards. Small parts of the flank shell are preserved in MB.C.3441. These show a very deep flank sinus and dense spacing $(0.05-0.1 \mathrm{~mm})$ of weakly developed growth lirae which may be bundled. There are no traces of spiral furrows or constrictions on any of the moulds.

MB.C. 3432.2 shows sutures from $3.5 \mathrm{~mm}$ wh on (Fig. 1F). All lobes are present but are still more or less rounded. At all stages, $A_{1}$ is considerably deeper than $L_{1 v}$ and the $L_{1 v}-A_{1}$ saddle is higher than the other flank saddle. The outer ventral saddle is always relative broad and asymmetric. Initially $A_{2}$ is rather small and much shorter than $L_{1 v}$ (Fig. 1F). The $A_{1}$ is dominant at $3.5 \mathrm{~mm}$ wh. Between 3.5 and $5 \mathrm{~mm}$ wh, $\mathrm{L}_{1 \mathrm{v}}$ becomes pointed (Fig. 1E), followed by $A_{1}$ ca. between 6 and $9 \mathrm{~mm}$ wh, and eventually by $A_{2}$ at ca. $10 \mathrm{~mm}$ wh (Fig. 1G). With further growth, the flank saddles become more asymmetric and subtriangular (Figs 1B-D). Dorsal sutures are visible in several specimens and consist of a symmetrical, well-rounded $\mathrm{L}_{2}-\mathrm{L}_{1 \text { i }}$ saddle, a deep and pointed $\mathrm{L}_{1 \mathrm{i}}$ lobe, a narrow and high $\mathrm{L}_{1 \mathrm{i}}-\mathrm{I}$ saddle and a deep, narrow and pointed median $\mathrm{I}$.

Discussion: There is little variation in the general sutural pattern. No transitions towards Alp. kayseri or Alp. schultzei n. sp., both with inverse depths of flank lobes, have been observed. The ww/dm plot (Fig. 2A) shows marked differences between Alp. zigzag n. sp. and the other new species which is also evident in a comparison of $\mathrm{ah} / \mathrm{dm}$ ratios.

Stratigraphical range: As fas as known, Gonioclymenia hoevelensis Zone (UD V-B).

\section{Exotornoceras Becker, 1993}

Type-species: Gephyroceras superstes Wedekind, 1908.

\section{Manticoceras nehdense Lange, 1929}

Figs 3E-F, PI. 2: 1-2

Type: Holotype MB.C.3435, original of Manticoceras nehdense Lange (1929: text-fig. 1, pl. 1, fig. 1), suture see Fig. 3F.

Discussion: Since Langes original description of the only specimen from Nehden (Rhenish Massive) nothing additional became known about the species. The fate of most Lange types remained unknown. Becker (1993) revised Exot. superstes (Wedekind, 1908) and, based on Langes illustrations, stated that both species are identical. The surprising re-discovery of Langes type in the Museum für Naturkunde finally confirms this interpretation. For conch measurements see Table 1 .

A goniatite collection purchased near Erfoud unexpectedly yielded the first Moroccan representative of Exot. superstes (MB.C.3436). It is a small $(10.5 \mathrm{~mm} \mathrm{dm}, 6.3 \mathrm{~mm}$ wh $)$ haematitic mould showing typical sutures (Fig. 3E) and shell form. There are no marginal furrows as in juvenile Posttornoceras. Nothing is known about the locality and stratigraphic level within the eastern Anti-Atlas. Rich Nehdenian haematite faunas occur both in the Tafilalt and in the southern Maider.

Stratigraphical range: Restricted to the Paratorleyoceras globosum Zone (UD II-D).

\section{Posttornoceras Wedekind, 1910}

Type-species: Posttornoceras balvei Wedekind, 1910.

\section{Posttornoceras contiguum (Münster, 1832)}

Figs $3 \mathrm{~A}-\mathrm{B}, 4 \mathrm{~A}, 4 \mathrm{~B}, \mathrm{Pl} .2$ : 13-16

* 1832 Goniatites contiguus - Münster: 22, pl. 3, fig. 8

?e.p. 1839 Goniatites contiguus - Münster: 48

v e.p. 1840 Goniatites contiguus - Münster: 108 [e.p. $=$ Post. posthumum]

?* 1840 Goniatites contiguus var. b. subcontiguus - Münster 108 [nom. nud.]

1862 Goniatites contiguus - Gümbel: 303-304, 322, 323, pl. 1 , fig. 25

e.p. 1902 Sporadoceras contiguum - Frech: 82 [non fig. $35=$ Post. posthumum]

1908 Sporadoceras contiguum - Wedekind: 597: pl. XXXIX, fig. 46

?aff 1912 Sporadoceras contiguum var. - Sobolev: 12

aff. $1914 \gamma$-Gomi-dimeroceras (Posttornoceras) contiguum Sobolev: 58 , fig. 95 , pl. VIII, fig. 20

1918 Sporadoceras contiguum - Wedekind: 149 , fig. $47 \mathrm{~h}$

1921 Sporadoceras contiguum - Schindewolf: 160,188 


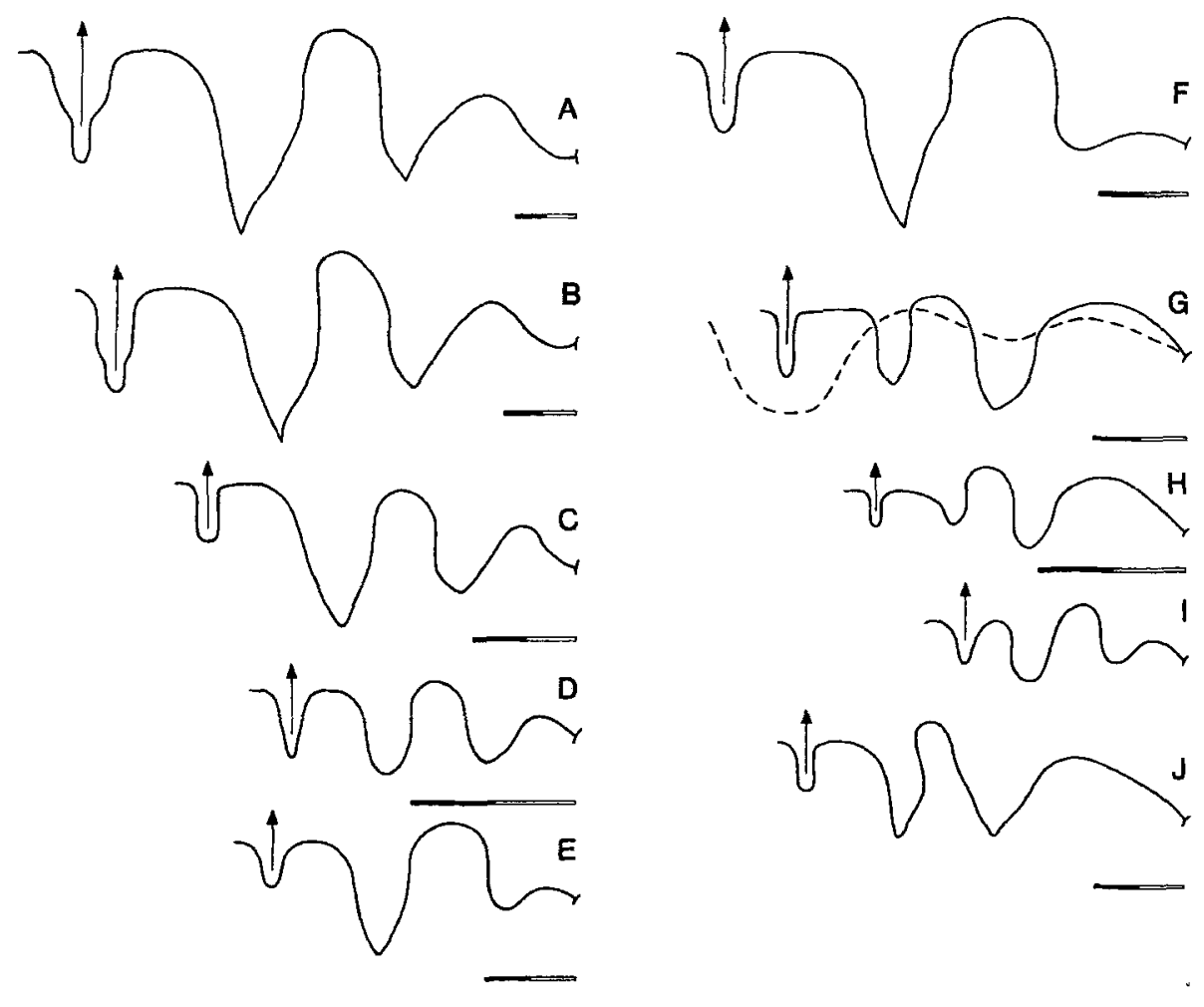

Fig. 3. Sutures (and a growth line) of various Posttornoceratidae. Scale bar $=2 \mathrm{~mm}$. A. Post. contiguum, MB.C.3455, from Enkeberg, Bed 18 of Paeckelmann \& Kühne 1936, upper Nehdenian, suture at $14.1 \mathrm{~mm}$ wh, B. Post. contiguum, MB.C.3462, Enkeberg, Prolobites delphinus Zone, UD III-C, suture (reversed) at $11.7 \mathrm{~mm}$ wh, C. Post. aff. contiguum, MB.C.3459, loose at Mrakib, UD III, suture (reversed) at $7.7 \mathrm{~mm}$ wh, D. Post. aff. contiguum, MB.C.3457, Mrakib, Bed J, UD III-C1, suture at $3.5 \mathrm{~mm}$ wh, E. Exot. superstes, MB.C.3436, loose from the Erfoud region, probably lower Nehdenian, suture (reversed) at ca. $6 \mathrm{~mm}$ wh, F. Exot. superstes, MB.C.3435, holotype of Manticoceras nehdense Lange (1929), Nehden, probably UD II-D, suture (reversed) at $10.2 \mathrm{~mm}$ wh, G. Maid. sapiens, MB.C.3468, loose from Mrakib, UD III, leg. V. Ebbighausen, suture and growth lines (reversed) at $8.5 \mathrm{~mm}$ wh, H. Maid. sapiens, MB.C.3447.2, Mrakib, Bed $\mathrm{H}_{1}$, basal UD III-C1 (based on first Pricella), suture at $4.1 \mathrm{~mm}$ wh, I. Discoclymenia sp. juv., MB.C., MB.C.3467, loose from the Maider, probably UD V, suture at $1.58 \mathrm{~mm}$ wh, J. Maid. muelleri n. sp., MB.C.3437, original of Discoclymenia n. sp. Müller (1956), between Löhma and Öttersdorf, UD III-C, suture at $8.1 \mathrm{~mm}$ wh.

1923 Sporadoceras contiguum - Schindewolf: 348

1929 Sporadoceras contiguum - Lange: 13 , 56, fig. 8

v 1936 Sporadoceras contiguum - Paeckelmann \& Kühne: 27

v e.p. 1936 Sporadoceras n. sp. - Paeckelmann \& Kühne: 30

1938 Sporadoceras contiguum - Paeckelmann: 24

non 1953 Sporadoceras contiguum - Nalivkina: 95, pl. III,

figs $2-4[=$ Post. sodalis $]$

1957 Sporadoceras contiguum - Freyer: 51

?e.p. 1959 Sporadoceras posthumum - Petter: 275, fig. 58G, pl. XXII, fig. 7 [only]

cf. 1963 Sporadoceras cf. contiguum - House: 10 , fig. $4 \mathrm{c}$

non 1971 Posttornoceras contiguum Bogoslovskiy: 87-88, fig.

23, pl. 4 , fig. $8[=$ Post. sodalis $]$

non 1971 Sporadoceras contiguum Bogoslovskiy: 154-155,

fig. $46 \mathrm{c}$, pl. 12, figs $2-3$ [= Post. cf. sodalis $]$

? 1978 Sporadoceras contiguum Ruan: 3

v 1993 Sporadoceras contiguum Becker: 317-318, fig. 95j, pl.

26, figs 13-14 [further references]

non 1997 Posttornoceras contiguum Becker: 33, fig. 1a, pl. 1,

fig. 11 [= Post. aff. contiguum]

non 1999 Posttornoceras contiguum Korn: 155, text-fig. 5J [=Post. posthumum]

? 1999 Sporadoceras contiguum Sheng: 182

Type: Neotype MB.C.816.1, designated in Becker (1993).

Material: MB.C.816.1-3, MB.C.3454 (Pl. 2: 13-14, leg. v. Buch), MB.C.3455 (Pl. 2: 15-16, leg. Paeckelmann), MB.C.3456 and MB.C.3462 from Enkeberg, MB.C.3470 from Mrakib.
Discussion: The species has a long and difficult research history and it was hoped that the selection of a neotype would settle its status. However, Korn (1999) has questioned the neotype designation and since he used the taxon in a rather different sense (= Post. posthumum), it is necessary to outline and review its taxonomy once again.

The original description in Münster (1832) allows the species to be characterized as a moderately compressed (according to his illustration ww $20 \mathrm{~mm}$ at ca. $45 \mathrm{~mm} \mathrm{dm}$ ), medium-sized form with a relative low dorsolateral, a high mid-flank and a lower, relative broad ventral saddle. Münster $(1839,1840)$ continued collecting ammonoids and such later specimens, some of which were given to museums at Bayreuth, Berlin and Cambridge, cannot be regarded as syntypes. Experience with other taxa showed that Münster subsequently often included different forms under one species name. This is well expressed by the fact that Münster (1840) him- 
self recognized variants within his contiguus, but his var. subcontiguus remained an undescribed nomen nudum. During the revision of Münsters goniatites, based on the type material, Gümbel (1862) emphasized the compressed shell form of contiguus. This suggests that two Berlin specimens from Schübelhammer (MB.C.1697, figured in Becker 1995: ww $25 \mathrm{~mm}$ at ca. $50 \mathrm{~mm} \mathrm{dm}$; MB.C.3464: ww $13.3 \mathrm{~mm}$ at $18.4 \mathrm{~mm} \mathrm{dm}$ ) with rather thick whorls are not very close to the lost types from 1832. Most likely these specimens were not available to Gümbel during his revision since he concentrated on the Munich collection where figured specimens were deposited. In contrast to Korn (1999), both specimens are kept here in Post. posthumum. In terms of sutures and whorl widths (Fig. 4A), they are clearly conspecific with posthumum topotypes and the neotype. Gümbels (1862) suture illustrations of Münster originals, unfortunately, are not very conclusive since he shows three consecutive sutures with variable heights of saddles and lobe depths.

Frech (1902) assigned Gon. contiguus to Sporadoceras and used it, as Münster, in a rather wide sense, now including very large specimens. $\mathrm{He}$ stated its wide distribution in Silesia, the Montagne Noire, and at the Enkeberg in the Rhenish Massive. He also gave precise illustrations of sutures of a specimen of his own from Schübelhammer and of a second representative from Ebersdorf; both have rather high dorsolateral saddles as in Post. posthumum. Wedekind (1908) followed Frech and placed somewhat more compressed Enkeberg material from the Prolobites delphinus Zone (UD III-C) in contiguum. Frech (1913) recognized that most or all contiguum s.l. (= contiguum + posthumum) fall in Posttornoceras but until recently this was ignored by subsequent German authors. Wedekind (1918) eventually realized that there are two different forms in contiguum; somewhat thicker Dasbergian specimens with more asymmetric $\mathrm{A}_{2}$ were placed in his new var. posthuma, whilst contiguum was said to be restricted to the middle Hembergian (do III 3 = UD III-C). Wedekinds taxonomic concept was followed by Schmidt (1922, 1924), Schindewolf (1921, 1923) and subsequent German authors; posthumum was subsequently recognized on a near-global scale. Lange (1929) extended the range of typical contiguum into the upper Nehdenian which was confirmed by Becker (1993). Berlin Enkeberg collections from the contiguum (UD II-H, e.g., MB.C.3455, MB.C.816.1-3) and delphinus Zones
(UD III-C, MB.C.3462) show no difference in shell form or suture (Figs 1A-B). This partly also applies to Sporadoceras n. sp. of Paeckelmann \& Kühne (1936: MB.C.3456).

Supposed Post. contiguum were recorded from other regions of the world, such as southern France (Frech 1902, Schindewolf 1921), Poland (Sobolev 1912; $1914=$ aff. contiguum), NW Australia (Delepine 1935, = Sporad. angustisellatum), SW England (House 1963, Post. cf. contiguum), the southern Urals (Nalivkina 1953, Bogoslovskiy $1971,=$ Post. sodalis), and North China (Ruan 1978, Sheng 1999). In none of these cases has the identity with contiguum in the sense of German authors been sufficiently substantiated.

This history can be summarized in four theses: 1) The precise nature of Münsters (1832) originals is barely known but the species was described to be relatively compressed, (2) subsequent Münster material frequently included also a thicker form with higher inner flank saddle named by Wedekind (1918) as Post. posthumum, (3) a first more precise understanding commenced with Wedekind (1908) and concentrated on middle Hembergian goniatites, and (4) the middle Hembergian form ranged down into the upper Nehdenian.

In order to create taxonomic stability, and in the absence of a suitable (more compressed, inner flank saddle low) specimen from Schübelhammer, Becker (1993) selected a neotype from the upper Nehdenian of Enkeberg. This allowed a maximum of taxonomic continuity for German faunas and for posthumum. The neotype designation, however, was rejected by Korn (1999) on stratigraphic grounds, and he also suggested instead to use the thicker Schübelhammer specimen (MB.C.1697) figured by Becker (1995). As a consequence, and without any more precision concerning Münsters (1832) original concept, all Post. posthumum, as well as Korns (1999) Post. weyeri, would fall in a re-defined Post. contiguum whilst all German material assigned to contiguum in the $20^{\text {th }}$ century would have to be placed in a new taxon. Such taxonomic confusion is clearly unwanted and Post. posthumum is too widely recognized to be unnecessarily discarded. At the Schübelhammer type locality cephalopod limestones range from the late Nehdenian (UD II) to the Wocklumian (UD VI) and goniatite cross-sections have been observed below the annulata Zone which yields richer ammonoid faunas (oral comm. H. Tragelehn, Cologne). Typical Nehdenian goniatites have not 
been described from the section but it is not possible to be dogmatic about the type horizon of Münsters originals. It is possible that Münsters 1832 originals are identical with somewhat more compressed relatives of Post. posthumum (identified as Sporad. n. sp. aff. posthumum in Schindewolf 1937) from the Wocklumian of the Rhenish Massive. But all this remains speculative, and since the use of topotypes is strongly recommended but not mandatory in neotype designation, only the selection of Becker (1993) offers taxonomic stability and, therefore, is kept here.

Stratigraphical range: Upper Nehdenian (UD II-H) to middle Hembergian (UD III-C).

\section{Posttornoceras aff. contiguum (Münster, 1840)}

Figs 3C-D, 4A, 4B, Pl. 2: 5-8

? 1912 Sporadoceras contiguum var. - Sobolev: 12

$1914 \gamma$-Gomi-dimeroceras (Posttornoceras) contiguum - Sobolev: 58 , fig. 95 , pl. VIII, fig. 20

v 1985 Sporadoceras posthumum - Becker: 31

v 1995 Posttornoceras aff. contiguum - Becker: 620-622, text-figs $7 \mathrm{a}-\mathrm{b}$, pl. 3 , figs $1-2$

v 1997 Posttornoceras contiguum - Becker: 33, fig. 1a, pl. 1, fig. 11

v 2000 Posttornoceras aff. contiguum - Becker \& House: 79, fig. 3

Material: MB.C.3457 (Pl. 2: 5-6), MB.C.3458 (Pl. 2: 7-8), MB.C.3459, MB.C.3461 (original of Becker 1995: pl. 3, figs 1-2) and MB.C. 3472 from Mrakib, MB.C.2175 from the Nie Brickwork Quarry.

Discussion: Becker (1995) described from the supposed upper Hembergian (UD IV) a posttornoceratid which was thought to differ from contiguum (sensu the neotype) in the somewhat widened lobe at the umbilicus and in elevated ventral saddles which are higher than all other flank saddles. This feature was also described in upper Hembergian "Sporadoceras contiguum" from the Kia section (Bogoslovskiy 1971) which, by contrast, are thicker and which do not show subtriangular $\mathrm{L}_{2}-\mathrm{L}_{1 \mathrm{v}}$ saddles. A review of contiguum material from Enkeberg suggest. The lectotype was still seen by M. R. House in 1966 (see shell data in Table 1). That the widening of $\mathrm{L}_{2}$ also occurs in its oldest representatives (UD II-H). Therefore, the ventral saddles (Figs 3C) are the more diagnostic feature of aff. contiguum. Moroccan specimens (Pl. 2: 5-8) have marked ventrolateral furrows at early stages; since similarly small Sauerland specimens are not yet known, it cannot be decided whether this feature allows an additional distinction. Juveniles from the Maider also show that the mid-flank lobe is more prominent than others from earliest stages on (Fig. 3D).
Stratigraphical range: Middle (UD III-C) to upper Hembergian (UD IV-B, level with oldest Cymaclymenia, e.g. MB.C.3472 from Mrakib, Bed P).

\section{Posttornoceras posthumum (Wedekind, 1918)}

Pl. 2: 3-4, 9-12, Pl. 3: 1-2

v e.p. 1840 Goniatites contiguus - Münster: 108

* 1918 Sporadoceras contiguum var. posthuma - Wedekind: 149, 171, text-fig. $47 \mathrm{k}$, pl. XVIII, fig. 13

1921 Sporadoceras Wedekindi - Schindewolf: 151, 160, 167, 173 [nom. nud.]

1922 Sporadoceras contiguum var. posthuma - Schmidt: 290 , 329 , fig. $6 \mathrm{e}$

* 1923 Sporadoceras Wedekindi - Schindewolf: 349-350, fig. $7 \mathrm{~b}$ [nom. nov.]

1924 Sporadoceras Wedekindi - Schindewolf: 99, 100

1924 Sporadoceras contiguum var. posthuma - Schmidt: 123

1931 Sporadoceras posthumum - Matern: 46-47

v 1937 Sporadoceras posthumum - Schindewolf: 15, 16, 29

aff. 1937 Sporadoceras n. sp. aff. posthumum - Schindewolf: $15,16,17,18,22,29$

1938 Sporadoceras posthumus - Paeckelmann: 28 [nom. vad.]

1950 Sporadoceras posthumum - Termier \& Termier: 59, pl.

CLII, fig. 54, pl. CLIII, fig. 37, pl. CXL, figs 19-22

e.p. 1950 Discoclymenia cucullata - Termier \& Termier: pl. CLIII, figs 41-43 [only]

1952 Sporadoceras posthumum - Schindewolf: cf. 284,285

1954 Sporadoceras posthumum - Pfeiffer: cf. 56,58 , cf. 59 pl. VII, fig 2, cf. fig. 1

1959 Sporadoceras posthumum - House: 318 , fig. 1c, pl. 6, fig. 3

e.p. 1959 Sporadoceras posthumum - Petter: 275, pl. XXII, fig. 6 [only]

cf. 1960 Discoclymenia aff. cornwallensis - Selwood: 175 , pl. 29 , fig. 3

v 1971 Sporadoceras (Sporadoceras) posthumum - Bogoslovskiy: 155-156, fig. $46 \mathrm{a}-\mathrm{b}$, pl. XIII, figs 1-3 [further synonymy]

cf. 1973 Sporadoceras cf. posthumum - House \& Butcher: 206

v non 1975 Sporadoceras posthumum - Petersen: 42, 45, text-figs 21E, 22A, 23, pl. 6, figs 1-3 [=Sporad. angustisellatum Wedekind]

1978 Sporadoceras posthumum - Ruan: 3

1981 Sporadoceras posthumum - Ruan: 53-54, fig. 24, pl. 10 , figs $23-26$

v non 1985 Sporadoceras posthumum - Becker: $31[=$ Post . aff. contiguum]

1985 Sporadoceras posthumum - Ruan et al.: 263

v 1995 Sporadoceras posthumum - Becker: 621, fig. 7d, pl. 3, figs 12-13

v 1996 Sporadoceras posthumum - Becker: 21, 22, 23, pl. 2, figs $3-4$

v 1997 Sporadoceras posthumum - Becker: fig. 1b

* 1999 Posttornoceras weyeri - Korn: 56, text-fig. 50, pl. 1, figs 3,5

cf. 1999 Posttornoceras cf. balvei - Korn: pl. 1, figs 4, 6 1999 Posttornoceras posthumum - Korn: 155 , text-fig. $5 \mathrm{~L}$ 1999 Posttornoceras contiguum - Korn: text-fig. $5 \mathrm{j}$

2000 Sporadoceras posthumum - Becker \& House: 40

Type: The Wedekind types, including the figured specimen wrongly called holotype in Matern (1931), instead of lectotype, have been lost at Göttingen. Neotype is MB.C.2176 (PI. 2: 9-10) from Hövel (designated in Becker 1997). 


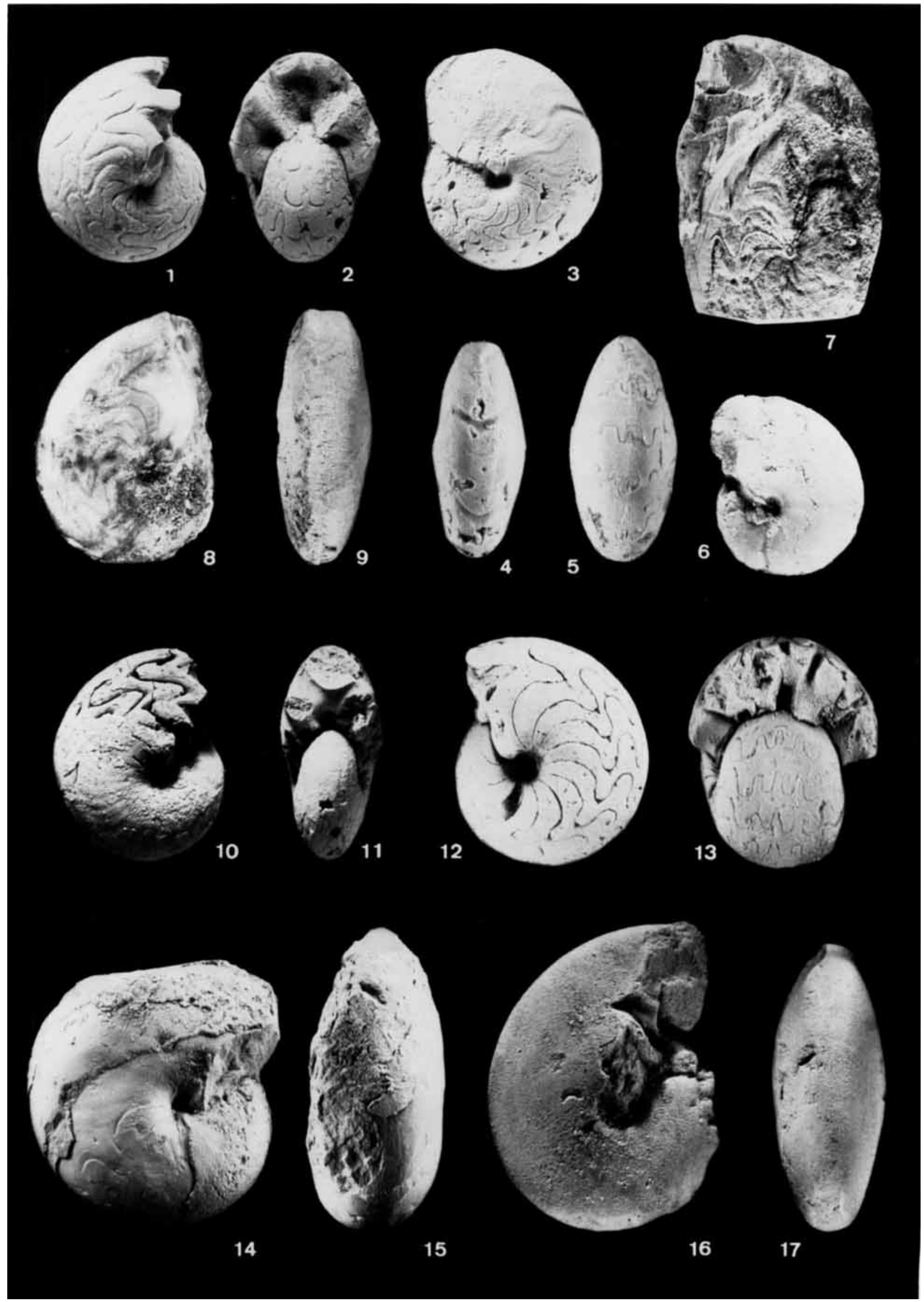


Material: Topotypes MB.C.3465.1-3, MB.C.3463.1-13 from Oberrödinghausen, MB.C.3464 and MB.C.1697 from Schübelhammer, MB.C.3446 (Pl. 2: 11-12), MB.C. 3451 (Pl. 2: 3-4) and MB.C.3453.1-5 from the Fezzou area, MB.C.3473 from Lambidia (NE Maider), MB.C.3452 (Pl. 3: 1-2, leg. V. Ebbighausen) from Mrakib, MB.C.3556 from S. France.

Discussion: Since Wedekinds original and any other possible syntypes have been lost at Göttingen, a neotype from the type locality has been selected. Schindewolfs Sporad. Wedekindi was introduced as an illegal name replacement (nom. nov.) and, therefore, should be treated as objective synonym. The species is easy recognizable by its inflated, relative fast expanding whorls (WER 2.5 - 2.68) and its characteristic sutures. It is widely distributed in Europe (e.g., new specimen from La Serre, trench C, Montagne Noire, MB.C.3556), North Africa, China and Russia but does not occur in Australia. Petersens (1975) material belongs to the older (UD III) and more compressed Sporad. angustisellatum. There is also a new record from eastern Iran (collected by the author in 1999).

Probably based on the rapid expanding whorls of Wedekinds (1918) original, Korn (1999) placed posthumum in Posttornoceras. This can be confirmed by a large haematitic Moroccan specimen (MB.C.3446, loose from the Fezzou area) with preserved incomplete traces of strongly biconvex growth lines. The flank sinus is very deep, followed by a projecting ventrolateral salient. There is no preserved ornament on any German specimen. Korn (1999) introduced a new species, Post. weyeri, for similar Moroccan forms but illustrated suture differences and shell form (Fig. 4B) lie in the range of intraspecific variation. This is confirmed by direct comparison of a Maider ("weyeri") population including various growth stages (e.g., MB.C.3451, MB.C.3453.1-5, small MB.C.3452 from Lambidia, leg. V. Ebbighausen) with the lectotype neotype and other topotypes, and with two specimens (MB.C.1697, MB.C.3464) from Schübelhammer. There are also no significant differences in shell form and parameters (Tab. 1, Figs 4A, 4 B).

Post. posthumum differs from Post. balvei in shell inflation and its longer outer flank $\mathrm{A}_{1}$ lobe, from Post. contiguum by somewhat thicker whorls and higher and more symmetric $\mathrm{L}_{2}-\mathrm{L}_{1 \mathrm{v}}$ saddle, from Post. aff. contiguum by the same features, by lower ventral saddles and by the lack of juvenile ventrolateral furrows, and from the equally thick (Figs 4A, 4B) Post. sodalis by higher inner flank saddles and $A_{1}-E$ saddles which are lower than the $L_{1 v}-A_{1}$ saddle. An undescribed compressed Posttornoceras from UD III-C of the Nie Brickwork Quarry with spiral double furrows at median size (Becker 1985, 1995), unfortunately, is currently not available for further study. Post. changshunense (Sheng, 1985) was thought to be somewhat more subglobular than posthumum but it is indistinguishable from the latter in the ww/wh plot (Fig. 4A) and does not differ much from thickest German posthumum (ontogenetic trait of MB.C.3465.1 in Fig. 4B) in the wh/dm plot.

Schindewolf (1924) described but did not illustrate his Discoclymenia Seidlitzi from Saalfeld which he stated to differ from Post. posthumum by the insertion of a shallow additional adventitious lobe in the ventral saddle. Several Maider posthumum specimens (e.g., MB.C.3446, MB.C.3451) leave the impression of a very slight concavity on top of the subrectangular ventral saddle. This is also seen in specimens from Oberrödinghausen (MB.C.3463.2), Schübelhammer (MB.C.1697), and even very weakly in one suture of the neotype. Since no type specimen of seidlitzi is available, the species currently has to be regarded as a nomen dubium. It could be argued to place posthumum as the most primitive

Plate 3. 1-2. Posttornoceras posthumum (Wedekind) juv., MB.C.3452, Mrakib, UD V, leg. V. Ebbighausen, lateral view, showing short inner flank saddles, ventral view, $\times$ 2.1. 3-4. Maideroceras sapiens $(\mathrm{Korn})$ juv., MB.C.3449.1, Mrakib, Bed $\mathrm{H}_{2}, \mathrm{DU}$ III-C1, lateral view, showing markedly biconvex growth ornament, ventral view, showing deep mould constrictions, $\times 3$. 5-6. Maideroceras sapiens (Korn) juv., MB.C.3474, Mrakib, loose in UD III, ventral view, $\times 5$, lateral view, showing constrictions with only very shallow flank sinus and wide inner flank saddle, $\times$ 4. 7. Discoclymenia sp. indet., BGR X4902, holotype of Gon. lenticularis Richter (1848: pl. 5, figs 127-128), Bohlen, UD V/VI, lateral view, $\times 2$. 8-9. Maideroceras muelleri $\mathrm{n}$. sp., MB.C.3437, holotype, original of Discoclymenia n. sp. Müller (1956: fig. 14, pl. 1, fig. 15), between Löhma and Öttersdorf, UD III-C, lateral and ventral views, $\times 3$. 10-11. Discoclymenia sp. juv., MB.C.3467, southern Maider, loose, probably from UD V, lateral view, showing strongly falcate growth ornament, unlike as in Maid. sapiens, adoral view, $\times 3$. 12-13. Sporadoceras orbiculare (Münster) juv., MB.C.3475, $1 \mathrm{~km} \mathrm{E}$ of Fezzou, probably UD V, leg. V. Ebbighausen, lateral and adoral views, $\times 3.1$. 14-15. Sporadoceras muensteri (v. Buch), Bayrische Staatssammlung für Paläontologie und Historische Geologie, Munich, AS VII 1143, Schübelhammer, age unknown, lateral and ventral views, showing equally long flank lobes and thick whorls, $\times 1$. 16-17. Sporadoceras brachylobum Frech, Geologisch-Paläontologisches Institut und Museum, Göttingen, 390-707, original of Becker (1995: fig. 7d), Enkeberg, precise age unknown, lateral and ventral views, showing compressed whorl form, $\times 2$. 

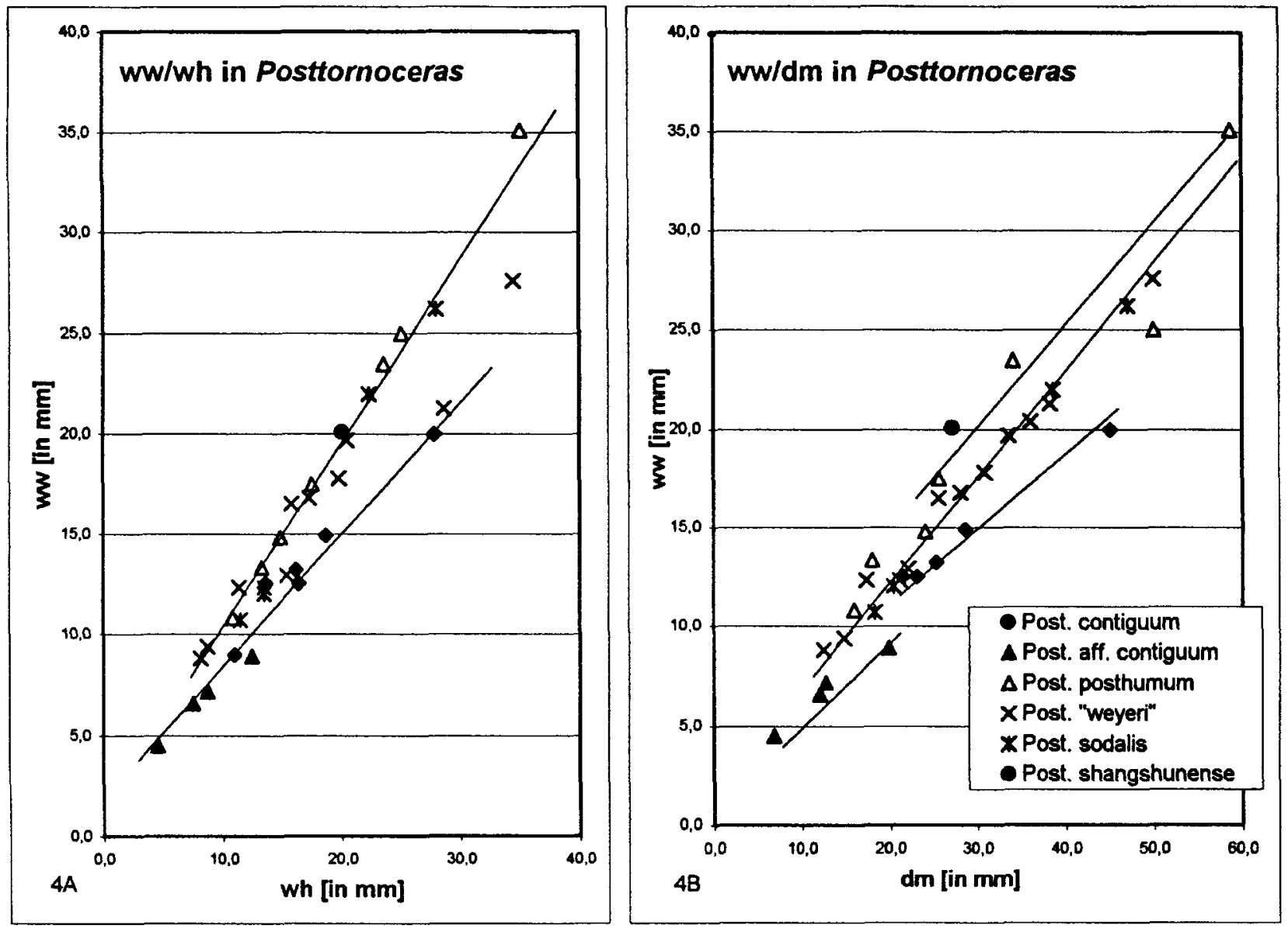

Fig. 4. Ww/wh (A) and ww/dm (B) ratios of Post. contiguum from Enkeberg, Post. aff. contiguum from the Maider, Post. sodalis (based on data in Bogoslovskiy 1971), Post. changshunense (based on Sheng 1985), and of Sporad. posthumum from Morocco (including Post. weyeri sensu Korn) and Germany (Hövel, Schübelhammer). Post. contiguum and aff. contiguum differ by stronger shell compression in both plots whilst the "weyeri population" mostly falls in the field of Post. posthumum. The Post. changshunense holotype is not very different from thickest posthumum topotypes (upper line = ontogenetic trajectory of MB.C.3465.1).

species in Discoclymenia but based on Maider material this is rejected since there is not yet any additional fold of the septal surface.

\section{Stratigraphical range: Upper Hembergian} (UD IV-C) to upper Wocklumian (UD VI-D).

\section{Discoclymenia Hyatt, 1884}

Type-species: Goniatites Haueri Münster, 1840, alleged subjective synonym of Gon. cucullatus v. Buch, 1839.

Remarks: The author (Becker 1995) has intensively investigated the difficult taxonomic history of the genus. Rich material from Morocco and some specimens from the Carnic Alps, Rhenish Massive and Thuringia confirm previous suspicions (e.g., Schindewolf 1924, Petter 1959) that several species can be recognized in the genus. For this reason, clear type designations and diagnosis of previously established taxa are required which, unfortunately, are not yet possible. But some observations on discoclymenids from different areas are given.

\section{Discoclymenia cucullata (v. Buch, 1839)}

* 1839 Goniatites cucullatus - v. Buch: 156, pl. 1, fig. 4 1995 Discoclymenia cucullata - Becker: 622-624, figs $8 \mathrm{~b}-\mathrm{d}$, pl. 3, figs 3-7 [extensive synonymy]

Type: The Berlin type specimen was last seen by Frech (1902) but has been lost since. A neotype needs to be selected from Dzikowiec (Ebersdorf). Unfortunately, the rich Ebersdorf collections of Schindewolf was burnt in Berlin during the $2^{\text {nd }}$ World War and no other topotype is currently available to the author.

Discussion: A partly reconstructed cross-section of the lost type was illustrated by Frech (1902). The rounded flanks and adult ww/dm ratio $=0.3$ is nearly the same as in larger Maider discoclymeniids (e.g., MB.C.3445.1-2). This justifies the previous assignments of the Moroccan and common Rhenish form to Disco. cucullata. 


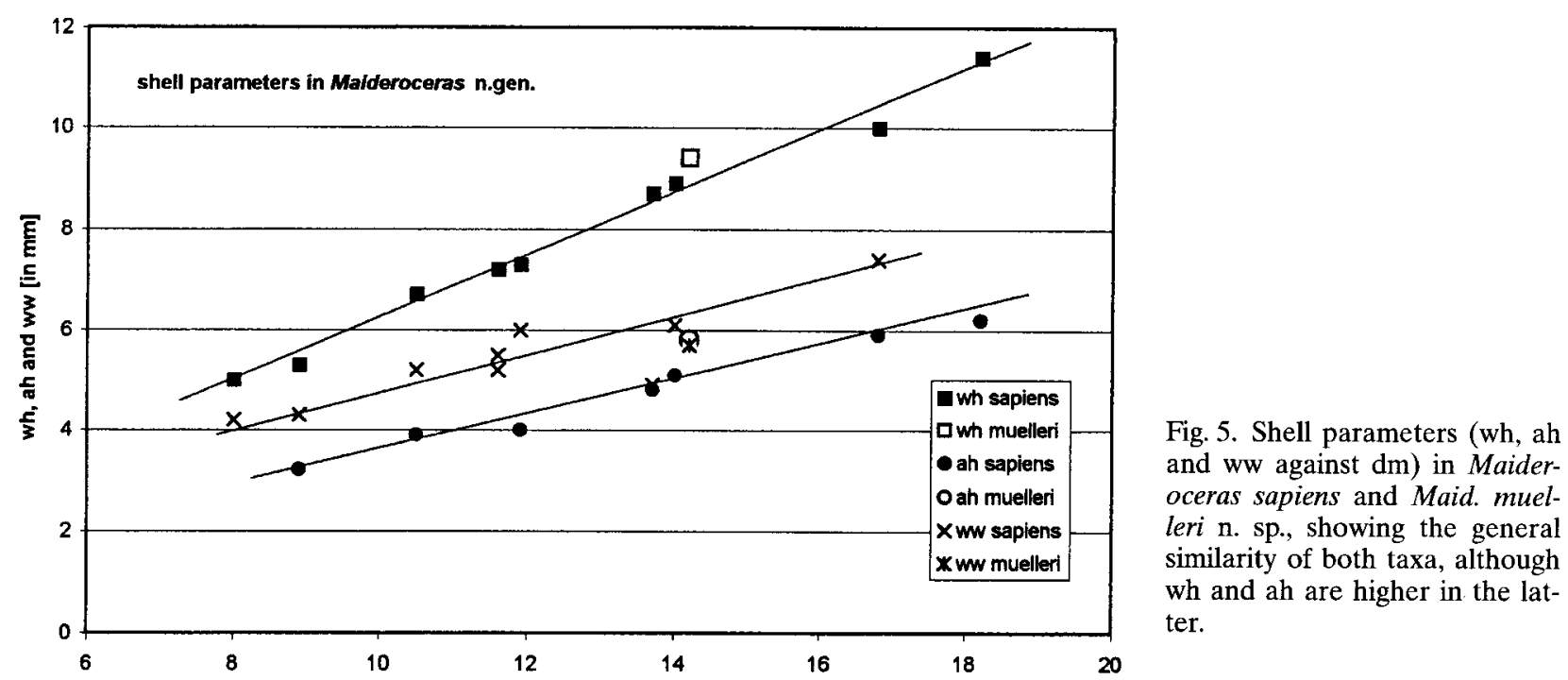

Stratigraphical range: Basal Dasbergian (UD V-A1) to upper Wocklumian (UD VI-D).

\section{Goniatites lenticularis Richter, 1848}

Pl. 3: 7

* 1848 Goniatites lenticularis Richter: 36, pl. 5, figs 127-128

Type: Holotype (by monotypy) BGR X4902.

Discussion: Apart from an early review by Gümbel (1862), the various goniatite taxa introduced by Richter (1848) have not been properly revised. Examination of the type of Gon. lenticularis confirmed that this species from the Bohlen of Saalfeld (Thuringia) has a typical Discoclymenia-suture with a dominant, very deep $\mathrm{A}_{1}$ lobe (e.g., as in MB.C.3438 from Langenaubach). The flanks are rounded and converge to a rounded venter. However, the specimen is so poorly preserved that no reliable shell parameters can be given. Richters species probably is a subjective synonym of Gon. cucullatus v. Buch from Silesia. But since species in Discoclymenia will be mainly distinguished by shell form, the monotypic taxon is best regarded as a nomen dubium.

A second Famennian tornoceratacean has been described by Richter (1848: 28, pl. 3, fig. 66) as Clymenia (Nautilus) polytrichus Roemer, 1843 but, quite correctly, Gümbel (1862) stated that Richters specimen was not identical with Roemers species which may be a Carboniferous goniatite (nom. dub.). Schmidt (1924; see synonymy list in Becker 1995) commented that Richter's original (BGR X4873) may be identical with Gundolficeras escoti (Frech) but this was not confirmed by re-examination. The original is very poorly preserved and fragmentary. The shell is compressed and tegoid and there are eroded sutures with rather wide mid-flank Alobes as in Falcitornoceras. The ventral saddle is lower than the flank saddle, but no clear species identification is possible.

\section{Goniatites hercynicus Gümbel, 1862}

Type: Gümbel based his description on four individuals collected by Engelhardt at the Bohlen near Saalfeld but did not state where the material was deposited. The Engelhardt collection possibly remained in private hands and, therefore, may be lost. With respect to the demand for clear species definitions within Discoclymenia, selection of a neotype from the Bohlen is required.

Discussion: Gümbel illustrated the discoclymeniid suture of his species but did not provide precise data on shell form and parameters. This renders his taxon unrecognizable within the genus. Gümbel also didnot specify any differences between his species and Gon. lenticularis although both came from the same locality. As suspected by Gümbel himself, both are identical, and hercynicus most likely is a younger synonym of lenticularis and of cucullata. Clarification could come from Bohlen topotypes. Large Berlin collections from Thuringia by various authors include just one fragmentary Discoclymenia (MB.C.3444, leg. Heinrich \& Schwamm, middle part of Bed $10=$ UD V) which has the rounded, tegoid flanks and shell parameters (ww $9.6 \mathrm{~mm}$ at $17.6 \mathrm{~mm}$ wh) as in Disco. cucullata from Morocco (Becker 1995) and Russia (Bogoslovskiy 1971). Unfortunately, the only available specimen is too poor to become a hercynicus neotype. The same applies to the fragment figured by Pfeiffer (1954: pl. VI, fig. 6). 


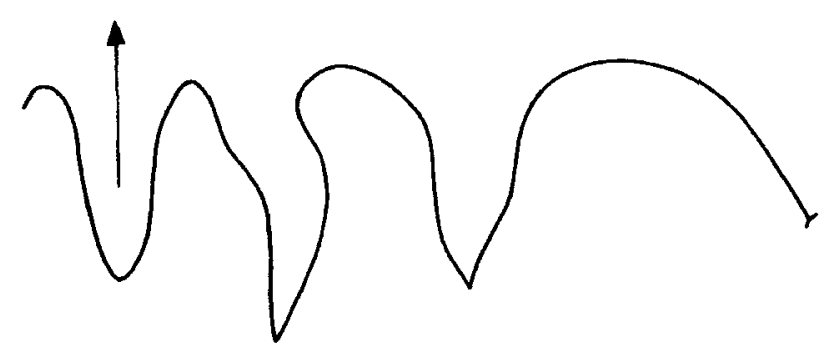

Fig. 6. Suture of Selwoodites n. sp. aff. cornwallensis, MB.C.3478, Oberrödinghausen, Bed 10, basal Kamptoclymenia endogona Subzone, UD VI-C1, leg. O.H. Schindewolf, at $19.5 \mathrm{~mm}$ wh.

\section{Discoclymenia haueri (Münster, 1840)}

Fig. 1I

* 1840 Goniatites Haueri - Münster: 109, pl. XVI, fig. 10 1863 Clymenia Haueri - Gümbel: $159-160$, pl. XXI, fig. 5 ? 1884 Goniatites Haueri - Beyrich: 218

?e.p. 1902 Sporadoceras cucullatum - Frech: 83, fig. 36d [only]

e.p. 1923 Wedekindoceras cucullatum - Schindewolf: textfig. 9 a, pl. 16, fig. 3 [only]

e.p. 1924 Wedekindoceras cucullatum - Schindewolf: 100-101

1959 Discoclymenia cucullata n.var.? - Petter: 211-212, pl. XV, fig. 16

Type: No type of this species from the Schübelhammer (= Köstenhof) in the Frankenwald has ever been selected. The specimen re-illustrated by Gümbel (1863) should be kept in the Bayrische Staatssammlung at Munich (seen by M. R. House in 1963); a Berlin syntype studied by Beyrich (1884) and figured by Frech (1902) also cannot be traced. Another specimen from Schübelhammer is currently not available.

Discussion: Measurements given in Münster (1840: $w w / d m=c a . ~ 0.25 ; 0.29$ at $24 \mathrm{~mm} \mathrm{dm}$ based on pl. XVI) and by Gümbel (1863: ww $12 \mathrm{~mm}$ at $40 \mathrm{~mm} \mathrm{dm},=0.30$, confirmed by M. R. House) observations suggest a more compressed species than Disco. cucullata (ww $14.6 \mathrm{~mm}$ at $41 \mathrm{~mm} \mathrm{dm},=0.36$; Becker 1995). It is unknown whether this was also true for the Berlin specimen examined by Beyrich (1884) and Frech (1902). Support for different shell form comes from the somewhat corroded original of Schindewolfs (1923) Disco. cucullata (MB.C.3443: ww only ca. $10 \mathrm{~mm}$ at nearly $40 \mathrm{~mm} \mathrm{dm},=0.25$ ). Extremely compressed and rather trochoid discoclymeniids were also mentioned by Schindewolf (1924) and from North Africa (Petter 1959). In addition there is a new small specimen (MB.C. 3439: ww $5.2 \mathrm{~mm}$ at $17.5 \mathrm{~mm} \mathrm{dm},=0.30$ ) from Malpasso (Bed 7c, UD V-A) above the Pramosio Alp in the Italian Carnic Alps. Current knowledge justifies to assign such thin forms to Disco. haueri.
Stratigraphical range: As far known, lower (UD V-A) to middle Dasbergian (UD V-B).

\section{Taxa excluded from the Posttornoceratidae}

\section{Maideroceras n. gen.}

Type-species: Posttornoceras sapiens Korn, 1999.

Derivation of name: After the type-region of the typespecies.

Diagnosis: Small-sized, earliest stages with small open umbilicus, later with closed umbilicus, strongly compressed, whorls relative fast expanding (adult WER 2.4-2.6), growth lines markedly biconvex with well-developed dorsolateral and ventrolaterial salients; sutures with wide $L-A_{1}$ saddle, pointed and asymmetric $A_{1}$ and $A_{2}$ lobes, small ventral lobe. Sutural formula: IULA $A_{1} A_{2} E$.

Included taxa: Maid. sapiens (Korn), Maid. muelleri $\mathrm{n}$. sp.

Discussion: In classical taxonomy tornoceratids were always thought to have biconvex growth lines whilst cheiloceratids and their descendents such as sporadoceratids have convex growth lines. Recent work showed a more complex morphological pattern with convex growth lines having evolved independently in the Frasnian Domanikoceras (Becker et al. 2001) and with slightly biconvex ornament re-appearing in the Famennian sporadoceratid Erfoudites (Korn 1999). The new genus differs from Sporadoceras and all other Sporadoceratidae by somewhat faster whorl expansion and by markedly biconvex growth lines (Fig. 3G, Pl. 3: 3) which, however, are not falcate (with much higher outer than inner salient) as in Posttornoceratidae (Pl. 3: 10). Posttornoceras with the same number of lobes partly possesses, as Falcitornoceras, ventrolateral furrows at small size (Pl. 2: 5-6), sitting in a tongue-like apertural projection. Early juvenile sutures give more important differences: in Posttornoceras, in accordance with a tripartite lateral lobe, the inner flank saddle is short and low and the mid-flank lobe is deeper than the first flank lobe (Fig. 3D). The same applies to juvenile Discoclymenia (Fig. 3I). In Maideroceras n. gen., by contrast (Fig. $3 \mathrm{H}$ ), the inner flank saddle is dominant as in all other sporadoceratids, and the first flank lobe is much deeper than the second. In other words, Posttornoceras has Exotornocerastype early sutures, Maideroceras has Maenecerastype early sutures. Maideroceras n. gen. represents a phylogenetic lineage which independently 
started to explore the eupelagic posttornoceratid morphospace.

Stratigraphical range: Lower (UD III-A/B) to middle Hembergian (UD III-C).

Geographical distribution: Southern Morocco (Maider), Thuringia.

\section{Maideroceras sapiens (Korn, 2001)}

Figs 3G-H, 5, Pl. 3: 3-6

1999 Sporadoceras n. sp. aff. heterolobatum - Becker et al.: $93,94,95$, fig. 38

1999 Sporadoceras n. sp. aff. heterolobatum var. - Becker et al.: 93,94 , fig. 38

1999 Posstornoceras sapiens - Korn: 156, text-fig. 5B, pl. 1, figs $1-2$

2000 Sporadoceras n. sp. aff. heterolobatum - Becker et al.: 78,79 , fig. 3

2000 Sporadoceras n. sp. aff. heterolobatum var. - Becker et al.: 78,79 , fig. 3

Type: Holotype GPIT 1850-30.

Discussion: Becker et al. (1999, 2000) recorded a new sporadoceratid from Mrakib in the southern Maider where it occurs abundantly in the regional Planitornoceras euryomphalum to Sulcoclymenia sulcata Zones (UD III-A to IIIC). Based on just two specimens from Rich Sidi Ali, also in the southern Maider, the same species was described by Korn (1999) as Post. sapiens. His tentative dating as Platyclymenia annulata Zone (UD IV-A) has to be corrected; rich collections of the annulata Zone of the southern Maider did not yield a single specimen of the taxon.

Not only the age assignment, but also the generic placement is changed since sapiens does not show some important Posttornoceras apomorphies: 1) a tripartite lateral lobe, indicated by a short dorsolateral saddle, (2) growth lines with highly projecting ventrolateral salient, deep lateral sinus and short and low dorsolateral salient. Korn was obviously led by a relative high WER (allegedly 2.58 in the holotype, but between 2.35 and 2.53 in Mrakib collections (e.g., MB.C.3471: WER 2.37 at $13.7 \mathrm{~mm} \mathrm{dm}$, MB.C.3447.1: WER 2.44 at $8.9 \mathrm{~mm} \mathrm{dm}$, MB.C.3476.1: WER 2.53 at $10.5 \mathrm{~mm} \mathrm{dm}$; see Table 1) to include his species in Posttornoceras. A range of observations, however, require the placing of sapiens in a new sporadoceratid genus: 1) from earliest observed stages on (MB.C.3447.1: at $2.8 \mathrm{~mm}$ wh, MB.C. 3471 at $2.4 \mathrm{~mm}$ wh; see Fig. $3 \mathrm{H}$ ), the inner flank saddle is rather wide (see also Pl. 3: 3) and the first flank lobe is much deeper than the second (compare different sutures in juvenile con- temporaneous Post. aff. contiguum, Fig. 3D, or in juvenile Discoclymenia, Fig. 3I), (2) shell thickenings (mould constrictions, Pl. 3: 4-6) are not known in any other species of the Posttornoceratidae (see Pl. 3: 9), (3) growth ornament impressed on small and well-preserved haematitic moulds, followed by constrictions (PI. 3: 6), is only weakly biconvex instead of falcate, with low dorsolateral salient, very shallow flank sinus and non-projecting ventrolateral salient, as in the sporadoceratid Erfoudites (see Korn 1999: fig. $6 \mathrm{C})$. Only with growth does the lateral sinus become marked (MB.C.3449.1, Pl. 3: 3; MB.C. 3471; MB.C.3468, Fig. 3G) but inner and outer flank salients remain more or less equally high.

The revised age would make sapiens one of the older Posttornoceras species, none of which displays a similarly compressed shell form. The WER slightly exceeds the values in Sporadoceras s.str. which lie ca. between 2.0 (e.g., Sporad. kiense) and a maximum of ca. 2.35 (e.g., Sporad. muensteri, see Bogoslovskiy 1971; see Pl. 3: $13-14)$. There is no reason why a higher WER should not have developed iteratively in the Sporadoceratidae. Trends to faster expanding and strongly compressed forms also occurred in the Cheiloceratidae and Dimeroceratidae (Paratornoceras lineage).

Stratigraphical range: Lower to middle Hembergian (UD III-A to III-C).

\section{Maideroceras muelleri $\mathbf{n} . \mathbf{s p .}$}

Fig. 3J, Pl. 3: 8-9

v 1956 Discoclymenia n. sp. Müller: 62-63, fig. 14 , pl. 1 ,
fig. 15 Holotype: MB.C.3437.

Type locality: Between Löhma and Öttersdorf, Thuringia.

Type level: Prolobites delphinus Zone (UD III-C), based on associated "Sporad." varicatum (Müller 1956: 15).

Derivation of name: In honour of K. J. Müller who collected and first described the holotype.

Diagnosis: Strongly compressed, with narrowly rounded venter, whorls rapidly expanding (WER ca. 2.8); sutures with broad inner flank saddle, $A_{1}$ v-shaped, $A_{1}-A_{2}$ saddle high, very narrow and asymmetric, $A_{2}$ asymmetrically pointed, as deep as $A_{1}$, ventral saddle high, asymmetric, E small.

Discussion: Müller (1956) correctly noted that his specimen belongs to a new species but his suture illustration needs to be corrected. An incipient $\mathrm{A}_{3}$ lobe was obviously artificially pro- 
duced by too strong grinding of the curved ventrolateral shoulders during preparation. The course of growth lines is unknown. The WER is much higher than in Sporadoceras but the wide lateral saddle is unlike as in Posttornoceras. Maid. muelleri n. sp. closely resembles Maid. sapiens and differs only in the higher WER, deeper $A_{2}$, and in the narrower $A_{1}-A_{2}$ saddles (Fig. 3J). In the majority of Moroccan sapiens specimens, $A_{2}$ is not as deep as $A_{1}$ (Fig. 3G) but there is some variation, often even between successive septa.

Differences from Sporadoceras species with asymmetric $\mathrm{A}_{2}$ are straight forward. Sporad. heterolobatum Lange, 1929 is also compressed but its whorls expand very slowly. Sporad. brachylobum Frech, 1902, as judged by topotype and possible neotype GPIG 390-707 (Göttingen collection, suture illustrated in Becker 1995: fig. 7d; see Pl. 3: 15-16), also has a lower ventral saddle, but is thicker and has a WER around 2.3. The insufficiently known Sporad. semiflexum Schindewolf, 1923 and Sporad. reticulatum Nalivkina, 1953 display a characteristic convexity in the deep $\mathrm{A}_{2}$-lobe; again both have slower expanding whorls.

\section{Selwoodites n. gen.}

e.p. 1960 Discoclymenia - Selwood: 174

Type-species: Discoclymenia cornwallensis Selwood, 1960.

Derivation of name: In honour of B. F. Selwood (Exeter) who discovered the type species and who made important contributions to the Devonian geology and palaeontology of SW England.

Included taxa: The type-species and Selwoodites n.sp. aff. cornwallensis.

Diagnosis: Shell involute, compressed, with well-rounded venter, moderately fast expanding (WER $<2.3$ ), growth-lines strongly concavo-convex with broad dorsolateral sinus and prominent, wide outer flank salient. Sutures with broad and high inner flank saddle, deep and pointed $\mathrm{A}_{1}$ lobe, even deeper, strongly asymmetric and angular $\mathrm{A}_{2}$ lobe, and high, subangular to angular ventral saddle with incipipent $A_{3}$ lobe; ventral lobe $v$-shaped. Sutural formula: $E\left(A_{3}\right) A_{2} A_{2} L U I$.

Discussion: The new genus differs in its peculiar course of growth ornament and sutures from all other genera of the Posttornoceratidae (growth-lines falcate biconvex) or Sporadoceratidae (growth-lines convex to biconvex). Due to its moderate whorl expansion and wide, sporadoceratid-type inner flank saddle, it is placed in the
Sporadoceratidae. Apart from the apertural shape, Selwoodites n. gen. differs from Sporadoceras also in the incipient $\mathrm{A}_{3}$. Simple subtriangular ventral saddles occur in the older Sporad. denticulatum Perna which displays convex growth lines. Maeneceras, Erfoudites and Iranoceras have rounded $\mathrm{A}_{2}$, Nothosporadoceras is open umbilicate, Araneites keeled. In Discoclymenia with fully developed small third flank lobe, it is the mid-flank, not the ventral saddle that becomes pointed; the ornament additionally is falcate with much narrower ventrolateral salient and with a smaller subumbilical salient. In all Posttornoceras (compare Korn 1999: text-fig. 5) the ventral saddle is very wide and subrectangular with flattened top.

The ornament has been well illustrated by Selwood (1960, pl. 28:23) and the same pattern is observed in a related new species from the lower to middle Wocklumian (UD VI-A to VI-C1) of the Rhenish Massive which has more symmetric $A_{1}$ lobes (Fig. 6) and spiral ornament. The Cornish species is somewhat younger and more advanced. Disco. aff. cornwallensis Selwood appears to be unrelated and is here, with some reservation (cf.), assigned to Post. posthumum.

Stratigraphical range: Wocklumian, UD VI-A (Sphenoclymenia brevispina Zone) to VIC2 (Parawocklumeria paradoxa Subzone).

Geographical distribution: Cornwall, Rhenish Slate Mountains.

\section{Phylogeny of the Posttornoceratidae}

The Famennian tornoceratid distribution and evolutionary history has been reviewed at length in Becker (1995). The new material and taxonomic revisions give further insights concerning the Posttornoceratidae which will be briefly outlined.

The oldest and morphologically most primitive member of the family is Exot. superstes (=nehdense, ?= niedzwiedzkii Dybczynski) from the Paratorleyoceras globosum Zone (UD II-D) of Germany, Poland and (new record) Morocco. Its angular A-lobe suggests that it may have been derived from early relatives of Gundolficeras escoti (Frech) but these are only poorly documented (e.g., Jux \& Krath 1974). As discussed above, the upper Famennian (UD V/VI) Exot. fezzouense group most likely branched off from a compressed relative of Gundolficeras delepinei. There are several undescribed forms in the UD 
III/IV of the southern Maider (Becker et al. 2000). Generic separation of the fezzouense Group should await the full documentation of this lineage. Re-exanimation of the original (MB.C.619) confirmed that Lobotornoceras delepinei of Bartzsch \& Weyer (1985) belongs to Exot. fezzouense. The original of Lobotornoceras bilobatum (MB.C.617) in the same publication is an advanced Falcitornoceras without a second lateral lobe at the umbilical seam.

The global Condroz events led to a record gap (Lazarus phase) in the Posttornoceratidae. Closely related first Posttornoceras with still rather low inner flank saddles appeared contemporaneously in UD II-H (regional Post. contiguum or Sporad. teicherti Zones) of Germany (e.g., MB.C.3454, leg. v. Buch, MB.C.3455-3456, leg. Paeckelmann), England (House 1963), perhaps Morocco, North China (Sheng 1999) and Russia (Urals) but this spread did not correlate with any eustatic pulse. Post. contiguum continued into the middle Hembergian (UD III-C) in Germany (Prolobites delphinus Zone, Wedekind 1908; e.g., at Enkeberg: MB.C.3456, leg. Paeckelmann, MB.C.3462; Freyer 1957), Morocco (e.g., MB.C.3470 from Mrakib, Bed $\mathrm{H}_{2}$ ), and, perhaps, Algeria; Post. glenisteri Petersen ranged equally high in Australia (regional Protactoclymenia euryomphala Zone). A posttornoceratid radiation can be recognized at this time: the rare and compressed Posttornoceras n. sp. with spiral double furrows appeared in the Northern Rhenish Massive (Becker 1985), Post. aff. contiguum with high ventral saddles and juvenile spiral furrows entered in Morocco (Becker et al. 2000: MB.C. 3457, MB.C.3458), the thick Post. sodalis Becker, also with high ventral saddle, occured in the Mugodzhar of southern Urals (Kara Dzhar and Manshia River, Bogoslovskiy 1971). All these forms may have descended from Post. contiguum and still have relative low inner flank saddles.

Post. aff. contiguum survived into the upper Hembergian (UD IV-B, Protoxyclymenia dunkeri Zone) of the Rhenish Massive (Becker 1997) and southern Morocco (e.g., squashed MB.C.3472). The ancestry of Post. balvei, known only from the annulata Zone (UD IV-A) of Germany, is somewhat enigmatic since the species has shorter A-lobes than any of the older species. Posttornoceratids from the UD IV of the Kia section of the southern Urals ("Sporad. contiguum" Bogoslovskiy 1971) are thicker than Post. aff. contiguum and, in this respect, resemble Post. sodalis. The first appearance of Post. posthumum $(=$ wedekindi, $=$ weyeri $)$ with high and better rounded inner flank saddles in the upper Hembergian (UD IV-C, Schindewolf 1923, 1924, 1952, Matern 1931) marks a next stage in the evolutionary history of the genus. The species probably descended from Post. balvei which also still has lower ventral than mid-flank saddles. Two somewhat intermediate individuals from Morocco were assigned by Korn (1999) to Post. cf. balvei. Post. posthumum became widespread in the Dasbergian (e.g., new Iran record). Somewhat more compressed relatives, named by Schindewolf (1937) as n. sp. aff. posthumum, ranged right to the base of the Hangenberg Blackshale and its equivalents. His final population (MB.C.3463.1-13) is in the Epiwocklumeria applanata Subzone (UD VI-D2) of the famous Oberrödinghausen railway cut. Posttornoceras, therefore, was amongst the victims of the global mass extinction close to the Devonian/Carboniferous boundary. The so far last known Moroccan Post. posthumum (MB.C.3473) occurs at Lambidia (Bed K) from a level with Kenseyoceras nucleus (UD VI-C2). The endemic Post. changshunense documents a trend to even thicker whorls at the same time in South China.

Discoclymenia entered at the very base of the Dasbergian (UD V-A1) in southern Morocco, Germany and in the Carnic Alps. The tegoid Disco. cucullata was found in the Endosiphonites muensteri Zone of the southern Tafilalt (Korn et al. 2000, also MB.C.3466.1-6 from Jebel Ouaouifilal) and in corresponding beds of the Heerstraße section of Thuringia (Brügge 1973). The trochoid Disco. haueri is here recorded from early Dasbergian beds of the Italian Carnic Alps which still lack Gonioclymenia. In Franconia it ranged into the Ornatoclymenia ornata Zone (UD V-B, Schindewolf 1923). The ancestry of the genus remains enigmatic since there is no intermediate, compressed Posttornoceras in the upper Hembergian (UD IV). Discoclymenia did not diversify significantly with time but Disco. cucullata persisted as a bradytelic form until the Hangenberg Event. The youngest known specimen comes from Bed 3 at Oberrödinghausen (Wocklumeria sphaeroides Subzone, UD VI-D1, Schindewolf 1937, MB.C.3460) but, according to the Signor-Lipps sampling effect, the species may have reached the main extinction level at the end of UD VI-D2.

A cryptogenic appearance is also true for Alpinites which first entered in the latest Hembergian (UD IV-C) of Morocco (Alp. schultzei n. sp) and of Kazakhstan (Alp. kajraktensis n. sp.). 
Both species still have narrowly rounded venter. Since Alpinites has more complex sutures than Discoclymenia, its earlier appearance is enigmatic. Either there is a still undetected primitive discoclymeniid (for example, without pointed flank saddle) in the late UD IV, or both genera may not have been as closely related as mostly thought. Alpinites with rounded venter probably gave rise to the oxyconic Alp. kayseri and, perhaps by paedomorphic shortening of the first flank lobe, to the somewhat younger Alp. zigzag n. sp. Currently there is no reliable record of $\mathrm{Al}$ pinites from younger strata than UD V-B.

\section{Acknowledgements}

The author likes to express many thanks to V. Ebbighausen, J. Bockwinkel and Z.S. Aboussalam for supplying their various collections of Moroccan Upper Devonian ammonoids. Other material came via D. Korn from A. Reisdorf (Tübingen). Mrs. S. Loewenich (Münster) produced suture drawings, Mrs. W. Harre and Mrs. G. Radke (both MfN, Berlin) assisted in the photographic work. $H$. Jahnke enabled access to the Göttingen collection. Fieldwork in Morocco was partly financed by the DFG. M.R. House (Southampton) and D. Weyer (Berlin) kindly reviewed and improved the manuscript which was written during a stay as guest researcher at the Museum für Naturkunde.

\section{References}

Bartzsch, K. \& Weyer, D. 1985. Zur Stratigraphie der Oberdevon-Quarzite von Saalfeld im Thüringischen Schiefergebirge. - Freiberger Forschungshefte C400: 5-36.

Becker, R. T. 1985. Devonische Ammonoideen aus dem Raum Hohenlimburg-Letmathe (Geologisches Blatt 4611 Hohenlimburg). - Dortmunder Beiträge zur Landeskunde, naturwissenschaftliche Mitteilungen 19: 19-34.

- 1993. Stratigraphische Gliederung und AmmonoideenFaunen im Nehdenium (Oberdevon II) von Europa und Nord-Afrika. - Courier Forschungsinstitut Senckenberg 155: $1-405$.

- 1995. Taxonomy and Evolution of Late Famennian Tornocerataceae (Ammonoidea), Berliner geowissenschaftliche Abhandlungen E16: $607-643$.

- 1996. New faunal records and holostratigraphic correlation of the Hasselbachtal D/C-boundary auxiliary stratotype (Germany). - Annales de la Société géologique de Belgique 117 (1): 19-45.

- 1997. Eine neue und älteste Glatziella (Clymeniida) aus dem höchsten Oberdevon des Nordsauerlandes (Rheinisches Schiefergebirge). - Berliner geowissenschaftliche Abhandlungen, E25: 31-41.

Becker, R. T. \& House, M. R. 2000. The Famennian ammonoid succession at Bou Tchrafine (Anti-Atlas, Southern Morocco). - Notes et Mémoires du Service Géologique 399: $37-42$.

Becker, R. T., Bockwinkel, J., Ebbighausen, V. \& House, M. R. 1999. Jebel Mrakib, Anti-Atlas (Morocco), a potential Upper Famennian substage boundary stratotype section. In El Hassani, A. \& Tahiri, A. (Eds): SDS - IGCP 421 Morocco Meeting, April $23^{\text {rd }}-$ May $1^{\text {st }} 1999$, Excursion Guidebook, Part 1: Tafilalt and Maider (eastern Anti-Atlas): 91-107, Institut Scientifique, Rabat.

- 2000. Jebel Mrakib, Anti-Atlas (Morocco), a potential Upper Famennian substage boundary stratotype section.
- Notes et Mémoirs du Service Géologiques 399: 75-86.

Becker, R. T., House, M. R., Menner, V. V. \& Ovnatanova, N. S. 2001. Revision of ammonoid biostratigraphy in the Frasnian (Upper Devonian) of the Southern Timan (Northeast Russian Platform). - Acta Geologica Polonica S0 (1): 67-97.

Beyrich, E. 1884. Erläuterungen $\mathrm{zu}$ den Goniatiten L. v. Buchs. - Zeitschrift der deutschen geologischen Gesellschaft 36: 203-219.

Bogoslovsky, B. I. 1962. Devonian Ammonoids. In Orlov, A. (ed.): Osnovy Paleontologii, Molyuski goloronoyie I: 334-425, Moskva.

- 1971. Devonskie ammonoidei. II, Goniatity. - Trudy Paleontologicheskogo Institut 127: 1-228 (in Russian).

Brügge, N. 1973. Zur stratigraphischen Einstufung des Oberdevon-Profils "Alte Heerstraße" bei Schleiz, Bezirk Gera. - Zeitschrift für geologische Wissenschaften 1 (3): 319-327.

Buch, L. von 1832. Über Goniatiten. - Abhandlungen der Königlichen Akademie für Wissenschaften zu Berlin 1830: 159-187.

- 1839. Über Goniatiten und Clymenien in Schlesien. Abhandlungen der Akademie der Wissenschaften zu Berlin 1838: $149-169$.

Czarnocki, J. 1989. Klimenie gór Swietokrzyskich. - Prace Panstwewo Instytut Geologicze 127: 1-91.

Flügel, H. \& Kropfitsch-Flügel, M. 1965. Ammonoidea palaeozoica. - Catalogus Fossilium Austriae, VIf4, 31 pp.

Frech, F. 1902. Über devonische Ammoneen. - Beiträge zur Paläontologie und Geologie von Österreich-Ungarns und des Orients 14 (I/II): 27-112.

- 1913. Ammoneae Devonicae (Clymeniidae, Aphyllitidae, Gephyroceratidae, Cheiloceratidae). Fossilium Catalogus, I: Animalia, 42 pp., W. Junk, Berlin.

Freyer, G. 1957. Neue Untersuchungen im Oberdevon des Vogtlandes auf Grund des Fossilinhaltes der Kalke im Bereich der Vogtländischen Hauptmulde. - Freiberger Forschungshefte C27: 1-100.

Gaertner, H. R. von 1931. Geologie der Zentralkarnischen Alpen. - Denkschriften der Österreichischen Akademie der Wissenschaften, mathematisch-naturwissenschaftliche Klasse 102: 113-199.

Gümbel, C. W. 1862. Revision der Goniatiten des Fichtelgebirges. - Neues Jahrbuch für Mineralogie, Geognosie, Geologie und Petrefacten-Kunde 1862: 284-326.

- 1863. Über Clymenien in den Übergangsgebilden des Fichtelgebirges. - Palaeontographica 11: 85-165.

House, M. R. 1959. Upper Devonian Ammonoids from North-West Dartmoor, Devonshire. - Proceedings of the Geologists Association 70 (4): 315-321.

- 1963. Devonian ammonoid successions and facies in Devon and Cornwall. - Quarterly Journal of the Geological Society London, 119: 1-27.

House, M. R. \& Butcher, N.E. 1973. Excavations in the Upper Devonian and Carboniferous rocks near Chudleigh, South Devon. - Transactions of the Royal Geological Society of Cornwall 20 (3): 199-220.

Jux, U. \& Krath, J. 1974. Die Fauna aus dem mittleren Oberdevon (Nehden-Stufe) des südwestlichen Bergischen Landes (Rheinisches Schiefergebirge). - Palaeontographica, Abteilung A 147 (4-6): 115-168.

Korn, D. 1981. Ein neues Ammonoideen-führendes Profil an der Devon-Karbon-Grenze im Sauerland (Rhein. Schiefergebirge). - Neues Jahrbuch für Geologie und Paläontologie, Monatshefte 1981 (9): 513-526.

- 1999. Famennian Ammonoid Stratigraphy of the Mader and Tafilalt (Eastern Anti-Atlas, Morocco). - Abhandlungen der Geologischen Bundesanstalt 54: 147-179.

Korn, D. \& House, M. R. 1997. Late Devonian and Early Carboniferous ammonoid faunas from the Carnic Alps. In Feist, R. (ed.): First International Conference on North Gondwanan Mid-Palaeozoic Biodynamics, Vienna: 17-21 September 1997, Meeting Program and Abstracts: 40-41, 
Geologische Bundesanstalt, Vienna.

Korn, D., Klug, C. \& Reisdorf, A. 2000. Middle Famennian ammonoid stratigraphy in the Amessoui Syncline (Late Devonian; eastern Anti-Atlas, Moroco). - Travaux de l'Institut Scientifique, Rabat, Série Géologie \& Géographie Physique 20: 69-77.

Lange, W. 1929. Zur Kenntnis des Oberdevons am Enkeberg und bei Balve (Sauerland). - Abhandlungen der Preußischen Geologischen Landesanstalt, Neue Folge 119: $1-112$.

Matern, H. 1931. Das Oberdevon der Dill-Mulde. - Abhandlungen der Preußischen Geologischen Landesanstalt, Neue Folge 34: 1-147.

Müller, K. J. 1956. Cephalopodenfauna und Stratigraphie des Oberdevons von Schleiz und Zeulenroda in Thüringen. Beihefte zum Geologischen Jahrbuch 20: 1-93.

Münster, G., Graf zu 1832. Über die Planuliten und Goniatiten im Übergangs-Kalk des Fichtelgebirges. - 38 pp., Bayreuth.

- 1839. Nachtrag zu den Goniatiten des Fichtelgebirges. Beiträge zur Petrefactenkunde 2: 43-60 (2. Auflage).

- 1840. Die Versteinerungen des Übergangskalkes mit Clymenien und Orthoceratiten von Oberfranken. - Beiträge zur Petrefactenkunde 3: 33-121.

Nalivkina, A. K. 1953. Verkhnedevonski goniatity i klimeni Mugodzhar. - Trudy VNIGRI, nova seria 72: $60-125$.

Paeckelmann, W. 1938. Erläuterungen zu Blatt Balve. Geologische Karte von Preussen und benachbarten deutschen Ländern, 2655 (neue Nr. 4613): 70 pp., Preussische Geologische Landesanstalt, Berlin.

Paeckelmann, W. \& Kühne, F. 1936. Erläuterungen zu Blatt Madfeld. - Geologische Karte von Preussen und benachbarten deutschen Ländern, 2586: 79 pp. Preußische Geologische Landesanstalt, Berlin.

Petersen, M. S. 1975. Upper Devonian (Famennian) Ammonoids from the Canning Basin, Western Australia. - Journal of Paleontology, Memoir 8: $55 \mathrm{pp}$.

Petter, G. 1959. Goniatites Dévoniennes du Sahara. - Publications du Service Carte Géologiques de Algérie, Nouvelle Série, Paléontologie Mémoirs 2: 313 pp.

Pfeiffer, H. 1954. Der Bohlen bei Saalfeld/Thüringen. - Geologie, Beihefte 11: 1-105.

Richter, R. 1848. Beitrag zur Paläontologie des Thüringer Waldes: Die Grauwacke des Bohlens und des Pfaffenberges bei Saalfeld. I. Fauna. 48 pp., Dresden, Leipzig.

Roemer, F. A. 1843. Die Versteinerungen des Harzgebirges. 40 pp., Hannover.

Ruan, Yiping. 1978. The Zonation of Devonian Ammonoids in China. - Acta Stratigraphica Sinica 3 (2): 134-137.

- 1981. Devonian and earliest Carboniferous Ammonoids from Guangxi and Guizhou. - Memoirs of Nanjing Institute of Geology and Palaeontology, Academia Sinica 15: $1-151$.

Ruan, Yiping, Wang, Shangqui, Mu, Daocheng, Wu, Yi, He, Jianghan \& Liang, Jiande. 1985. New observations on the Upper Devonian Zaisha section of Luzhai, Guangxi. Journal of Stratigraphy 9 (4): 262-269.

Schindewolf, O. H. 1921. Versuch einer Paläogeographie des europäischen Oberdevonmeeres. - Zeitschrift der deutschen geologischen Gesellschaft 73: 137-223.
- 1923. Beiträge zur Kenntnis des Palaeozoikums in Oberfranken, Ostthüringen und dem Sächsischen Vogtlande. I. Stratigraphie und Ammoneenfauna des Oberdevons von Hof a. d. Saale. - Neues Jahrbuch für Mineralogie, Geologie und Paläontologie, Beilage-Band 49 (3/4): 250-357, 393-509.

- 1924. Bemerkungen zur Stratigraphie und Ammoneenfauna des Saalfelder Oberdevons. - Senckenbergiana 8; 63-96.

- 1937. Zur Stratigraphie und Paläontologie der Wocklumer Schichten. - Abhandlungen der preußischen geologischen Landesanstalt, neue Folge 178, 132 pp.

- 1944. Grundlagen und Methoden der paläontologischen Chronologie. 139 pp., Berlin.

- 1950. Grundfragen der Paläontologie. 506 pp., Schweizerbart, Stuttgart.

- 1952. Über das Oberdevon und Unterkarbon von Saalfeld in Ostthüringen. Eine Nachlese zur Stratigraphie und Ammoneen-Fauna. - Senckenbergiana 32 (5/6): 281-306.

Schmidt, H. 1922: Das Oberdevon-Culm-Gebiet von Warstein i. W. und Belecke. - Jahrbuch der Preußischen Geologischen Landesanstalt 41 (1): 254-339.

- 1924. Zwei Cephalopodenfaunen an der Devon-Carbongrenze im Sauerland. - Jahrbuch der Preußischen Geologischen Landesanstalt 44: 98-171.

Schönlaub, H. P., Jaeger, H., House, M. R., Price, J. D., Göddertz, B., Priewalder, H., Kriz, J., Walliser, O. H., Haas, W. \& Vai, B. 1980. Field Trip A: Carnic Alps. - Abhandlungen der Geologischen Bundesanstalt 35: 5-57.

Selwood, B. F. 1960. Ammonoids and trilobites from the Upper Devonian and Lowest Carboniferous of the Launceston area of Cornwall. - Palaeontology 3 (2): 153-185.

Sheng, Huaibin. 1985. Ammonoids. In Hou, Hongfei, Ji, Qiang, Wu, Xianghe, Xiong, Jianfei, Wang, Shitao, Gao, Lianda, Sheng, Huaibin, Wei, Jiayong \& Turner, S.: Muhua Sections of Devonian-Carboniferous Boundary Beds: 85-90, Geological Publishing House, Beijing.

- 1999. Late Devonian Ammonoid Fauna from Upper Daminshan Formation, Great Khingan Mts., Inner Mongolia. - Professional Papers of Stratigraphy and Palaeontology, Chinese Academy of Geological Sciences 27: 180-205.

Sobolev, D. 1912. O verchnem neodevone okrestnostej Kielec. - Izvestija Warschawskaho Polytechnitscheskaho Instituta 1912 (II): $1-14$

- 1914. Skizzen zur Phylogenie der Goniatiten. - 195 pp. Warszawa (in Russian with German summary).

Termier, H. \& Termier, G. 1950. Paléontologie Marocaine. II. Invertebres de l'Ere primaire. Fasc. III, Mollusques. Service de Géologie de Protectorat Francaise Maroc, Notes et Mémoires 78: $246 \mathrm{pp}$.

Wedekind, R. 1908. Die Cephalopodenfauna des höheren Oberdevon am Enkeberg. - Neues Jahrbuch für Mineralogie, Geologie und Paläontologie, Beilageband 26: 565-635.

- 1910. Posttornoceras balvei n. gen. n. sp. - Ein neuer Fall von Konvergenz bei Goniatiten. - Centralblatt für Mineralogie, Geologie und Paläontologie 1910: 768-771.

- 1918. Die Genera der Paläoammonoidea (Goniatiten). Palaeontographica 62: 84-184. 